\title{
STUDIES ON THE CIRRIPEDIAN
}

FAUNA OF JAPAN. IX. -

DISTRIBUTIONAL SURVEY OF

THORACIC CIRRIPEDS IN THE SOUTHEASTERN PART OF THE JAPAN SEA-

\section{$\operatorname{AUTHOR}(S)$ :}

Utinomi, Huzio

\section{CITATION:}

Utinomi, Huzio. STUDIES ON THE CIRRIPEDIAN FAUNA OF JAPAN. IX. -DISTRIBUTIONAL SURVEY OF THORACIC CIRRIPEDS IN THE SOUTHEASTERN PART OF THE JAPAN SEA-. PUBLICATIONS OF THE SETO MARINE BIOLOGICAL LABORATORY 1970, 17(5): 339-372

\section{ISSUE DATE:}

1970-02-21

URL:

http://hdl.handle.net/2433/175604

RIGHT: 


\title{
STUDIES ON THE CIRRIPEDIAN FAUNA OF JAPAN. IX. DISTRIBUTIONAL SURVEY OF THORACIC CIRRIPEDS IN THE SOUTHEASTERN PART OF THE JAPAN SEA ${ }^{\text {1) }}$
}

\author{
Huzro UTINOMI \\ Seto Marine Biological Laboratory, Sirahama \\ With Plate XVIII and 12 Text-figures
}

\section{Introduction and Acknowledgments}

In the autumn of 1935, about three decades ago, I made a monthlong trip to the Tohoku and Hokuriku Districts of northern Japan for collecting Thoracic cirripeds (Hiro, 1939a). At that time I was impressed that the littoral biotope and faunal components on the Japan-Sea coast in comparison with the east coast on the Pacific side are much monotonous, although the warm Tusima Current penetrates northerly to the west coast of Hokkaido and to the Tugaru Strait. Besides, R/V Sôyô-maru of the Imperial Fisheries Experimental Station made a general benthic survey on the continental shelf around the Japanese Islands during the years 19261930 and succeeded to collect twenty-five species of Thoracic cirripeds at offshore stations (Hrro, 1933). The other collecting data for the Japan-Sea side cirripeds were very few in the pre-war time. Fortunately, afterwards extensive collections and informations have been accumulated to my hand through the courtesies of many personnels (past and present) of the institutions in the concerned districts, as mentioned in the following text, to whom I am deeply indebted in persuing the distributional survey after the Second World War.

Among them, I wish to extend particularly my deepest thanks to Mr. Takehiko Kitam of the Sado Marine Biological Laboratory for providing with many photographs and to Dr. Saburo NishimuRA of our Laboratory for preparing a map (Fig. 12) for the present paper in addition to proper collectings.

\section{Systematics}

\section{LEPADOMORPHA}

\section{Family Scalpellidae PILSBRY}

\section{Pollicipes mitella (LINNÊ, 1767) カメノテ}

1) Contributions from the Seto Marine Biological Laboratory, No. 517.

Publ. Seto Mar. Biol. Lab., XVII (5), 339-372, 1970. (Article 22) 
Pollicipes mitella: G.B. Sowerby, 1833; Darwin, 1851, p. 316; Nilsson-Cantell, 1921, p. 163. Mitella mitella: PilsBry, 1907, p. 6; Krüger, 1911, p. 8; ВRосH, 1931, p. 27; Нiro, 1932b, p. 546; HiRo, 1939a, p. 202; KттAмi, 1968, p. 68.

Occurrence.-Interior of Ponsyoro Cave near Osyoro, west Hokkaido, leg. S. Motoda, 19/X '43; Iwanai, west Hokkaido, leg. S. Motoda, 29/IX '43; Esasi, west Hokkaido, leg. S. Motoda, 29/IX '43; Hakodate (Weltner, 1897: 252); Mutu Bay, Tappi-saki, Nezugaseki and Tôzinbô (Hrro, 1939a: 202); Hukaura, Tugaru Region, leg. K. Konno, 20/IX '69; Awasima and Sado Is. (Kitamr, 1968: 68); Abugasima in Toyama Bay, leg. K. Krkuchi; Turuga in Wakasa Bay, leg. M. Hrraguahr, '31; Oki Is., leg. T. Yamamoto, 27/VIII '64; Cheju-Dô Is., leg. S. Okuda, 14/VIII '36; Yosu and Mokpo, South Korea, leg. S. OkudA, 28/VIII '36; Okinosima, Tusima Strait, leg. S. Mryake, '32 and leg. Zool. Inst., Tokyo Univ.; Yosimi, west coast of Simonoseki, leg. Y. MrYa, 9/IX '69; Nokozima in Hakata Bay, leg. Y. Mrya, 10/X, '69.

Distribution.-Common all around Japanese Islands far southwards to Malayan waters. Ponsyoro Cave near Osyoro, west Hokkaido is the known northern limit of range.

\section{Smilium scorpio (AURIVILLIUS, 1894) トゲヒメミヨウガ}

Scalpellum scorpio Aurivillius, 1894, p. 46.

Scalpellum (Smilium) sexcornutum Pilsbry, 1897, p. 723; Weltner, 1922, p. 96.

Calantica scorpio: Broch, 1931, p. 6; HrRo, 1933, p. 13 (synonymy); Hiro, 1939a, p. 203.

Occurrence.-Off Tango, west of Wakasa Bay, 64-73 m (Weltner, 1922, p. 96); Toyama Bay, 50-70 m (Hrro, 1939a, p. 203).

Distribution.-Sporadically recorded from deep basin of Japan and southwards.

3. Scalpellum koreanum HIRO, 1933 チョウセンミョウガ

Scalpellum koreanum Hiro, 1933, p. 36, figs 10-11 and Pl. II, figs. 1-2.

Occurrence.-Off Pusan, Korea Strait (Sôyô-maru Benthic Survey Station 478: $35^{\circ} 12^{\prime} 30^{\prime \prime} \mathrm{N}, 129^{\circ} 21^{\prime} 00^{\prime \prime} \mathrm{E}, 101 \mathrm{~m}$ and Station $481: 35^{\circ} 16^{\prime} 38^{\prime \prime} \mathrm{N}, 130^{\circ} 10^{\prime} 00^{\prime \prime} \mathrm{E}, 143 \mathrm{~m}$ ).

\section{Family Iblidae (LEACH) AnNandale}

\section{Ibla cumingi DARWIN, 1851 ケハダエボシ}

For description see Hiro, 1937, p. 393, fig. 1.

Occurrence.-Yosimi coast of Simonoseki, attached to the peduncle of Pollicipes mitella, leg. Y. Mrya, 9/IX '69; Nokozima in Hakata Bay, leg. Y. MrYA, 10/X '69. Distribution.-Malay Archipelago, Gulf of Oman, Red Sea and southern Japan. 
Family Oxynaspididae (PILsbry) Nilsson-Cantell

5. Oxynaspis pacifica HIRO, 1951 カクトゲエボシ

Occurrence.-Nezugaseki, Yamagata-ken, attached to Antipathes (Suzuki, 1963, p. 13).

\section{Family Lepadidae (DARWin) Nilsson-Cantell}

6. Lepas anatifera LiNNÉ, 1767 エボシガイ

Occurrence.-Asamusi, Mutu Bay (Hiro, 1932b: 546); Hukaura, Aomori-ken, leg. K. Konno, 20/IX '69; Sado Is. (Kitami, 1968: 68); Niigata (Honma, 1968: 34); Toyama Bay (Hrro, 1939a: 204); Turuga, Hukui-ken, leg. T. Yasuda, 23/IX '66; Okinosima, Hukuoka-ken (Urinomi, 1949: 20).

\section{Lepas anserifera LINNÉ, 1767 カルエボシ}

Occurrence.-Hukaura, Aomori-ken, leg. K. Konno, 9/XI '68; Nezugaseki, Yamagata-ken (Hrro, 1939a: 204); Niigata (Honma, I968: 34); Sado Is. (KitamI, 1968: 68); Husiki, Toyama-ken (Hrro, 1939a: 204); Sigasima, mouth of Hakata Bay, leg. S. MiYaKe, 27/X'52.

\section{Lepas pectinata SPengler, 1793 ルリエボシ}

Occurrence.-Tassya, Sado Is. (KIтAMI, 1968: 69).

9. Lepas fascicularis ELLIS et SOLANDER, 1786 ウキエボシ (P1. XVIII, fig. 1)

Occurrence.-Tassya, Sado Is., leg. T. KiтAmi, 24/VII '68.

10. Conchoderma virgatum (SPENGLER, 1790) スジェボシ

Occurrence.-Off Siriyazaki, Aomori-ken (Hrro, 1939a: 205); Tassya, Sado, Is. leg. T. KrTAmi, 17/VII '63.

\section{Conchoderma virgatum hunteri (Owen, 1830) コスジェボシ}

(Pl. XVIII, fig. 2)

Occurrence.-Tassya, Sado Is., on set net, anchor-buoy and rope, leg. T. KITAmI, 10/XI '67 (KIтAмI, 1968: 69); Toyama Bay, on the carapace of the crab Portunus trituberculatus (HrRo, 1939a: 205). 


\section{Family Heteralepadidae NILSSON-CANTELL}

\section{Heteralepas quadrata (AURIVILLIUS, 1894) ムラサキハダカエボシ}

Alepas quadrata Aurivillius, 1894, p. 30, pl. II, figs. 16-17, pl. III, figs. 2, 6 and 12 (Java Sea). Heteralepas (Heteralepas) quadrata: Hiro, 1937, p. 406 (Seto; Synonymy).

Occurrence.-Nezugaseki and Kamo, Yamagata-ken, on Portunus trituberculatus (Suzuki, 1963: 13).

\section{Paralepas minuta nipponica UTINOMI, n. ssp. ウニハダカエボシ} Heteralepas (Paralepas) minuta (PhilippI): Hiro, 1933, p. 51, text-fig. 15, pl. II, fig. 4.

Occurrence.-Sôyô-maru Benthic Survey Station 547 (Off Etizen-misaki, Hukuiken; $35^{\circ} 56^{\prime} 50^{\prime \prime} \mathrm{N}, 135^{\circ} 54^{\prime} 07^{\prime \prime} \mathrm{E}, 172 \mathrm{~m}$ ), Station 581 (Toyama Bay; $37^{\circ} 11^{\prime} 30^{\prime \prime} \mathrm{N}$, $137^{\circ} 09^{\prime} 15^{\prime \prime} \mathrm{E}, 207 \mathrm{~m}$ ), Station 582 (Toyama Bay; $37^{\circ} 01^{\prime} 35^{\prime \prime} \mathrm{N}, 137^{\circ} 04^{\prime} 55^{\prime \prime} \mathrm{E}, 176 \mathrm{~m}$ ), Station 605 (North of Sado Island; 38 $31^{\prime} 00^{\prime \prime} \mathrm{N}, 138^{\circ} 31^{\prime} 37^{\prime \prime} \mathrm{E}, 139 \mathrm{~m}$ ) and Station 652 (Tugaru Strait; $41^{\circ} 27^{\prime} 08^{\prime \prime} \mathrm{N}, 140^{\circ} 23^{\prime} 00^{\prime \prime} \mathrm{E}, 110 \mathrm{~m}$ ). All attached to spines of Cidarid sea-urchins.

Remarks. - These Japanese specimens, all of which were collected by the Sôyômaru Benthic Survey from the four stations mentioned above in the Japan Sea, were unfortunately lost, so that could not be re-examined. However, as my previous description shows, they may be actually different from the typical form from the Mediterranean Sea. According to Darwin (1851, p. 160) and Broch (1927, p. 18), the typical form is only $4 \mathrm{~mm}$ long, oval in shape, lacking any dorsal keel on the capitulum and internally the caudal appendages are only 3-segmented. The Japanese specimens, on the other hand, are uniformly yellowish globular form having a feeble dorsal keel and internally 11-segmented long caudal appendages, notwithstanding their external resemblance.

PILSBRy (1953) reported another variant from off Palm Beach of Florida, North America in 60 to 80 fathoms and named it Paralepas minuta americana (n. ssp.) as a separate subspecies. This is a little larger ( $5.5 \mathrm{~mm}$ long, $5 \mathrm{~mm}$ wide), bearing red markings on the capitulum and only 3-segmented short caudal appendages internally. Accordingly, it seems best to rename this Japanese specimens collected only by the Sôyô-maru Benthic Survey as a separate variant of the typical Paralepas minuta for the time being.

\section{Family Poecilasmatidae (Annandale) Nilsson-Cantell}

\section{Octolasmis orthogonia (DARWIN, 1851) ウスエボシ}

Occurrence.-Tusima Strait: $34^{\circ} 20^{\prime} \mathrm{N}, 130^{\circ} 00^{\prime} \mathrm{E}, 120 \mathrm{~m}$, on hydroids (BRoch, $1931: 38)$. 
Distribution.-Indomalayan waters and Japan, on hydroids.

15. Octolasmis weberi (HoEK, 1907) オオウスエボシ

Occurrence.-Northeast of Sado Island (Sôyô-maru Benthic Survey Station 603: $38^{\circ} 41^{\prime} 30^{\prime \prime} \mathrm{N}, 138^{\circ} 42^{\prime} 05^{\prime \prime} \mathrm{E}, 210 \mathrm{~m}$ ) (Hrro, 1933: 58).

16. Octolasmis neptuni (MACDONALD, 1869)カニエラエボシ

(Fig. I)

Paradolepas neptuni MacDonald, 1869, p. 442.

Octolasmis Lowei forma neptuni MAcDonald: Hiro, 1937, p. 420, 626; Hiro, 1939a, p. 206 (on gills of Neptunus trituberculatus from Mutu Bay).

Octolasmis (Octolasmis) neptuni (MacDonald): Newman, 1961, p. 100, pl. 21 (synonymy).

Octolasmis (Octolasmis) neptuni hiroi Newman, 1961, p. 102 (on gills of Charybdis japonica from Hukuyama, Seto Inland Sea).

Octolasmis nepluni (MacDonalo): Wu, 1967, p. 276, fig. 2.

Occurrence.-Mutu Bay, on gills of Portunus trituberculatus (Hiro, 1939a: 306); Turuga Bay, on gills of Portunus trituberculatus, leg. T. YAsUdA, 23/IX '66; Pusan, South Korea, on gills of Portunus trituberculatus, leg. K. YAMAUchI, X '69.

Remarks.-All of the specimens from various localities are generally small-sized,
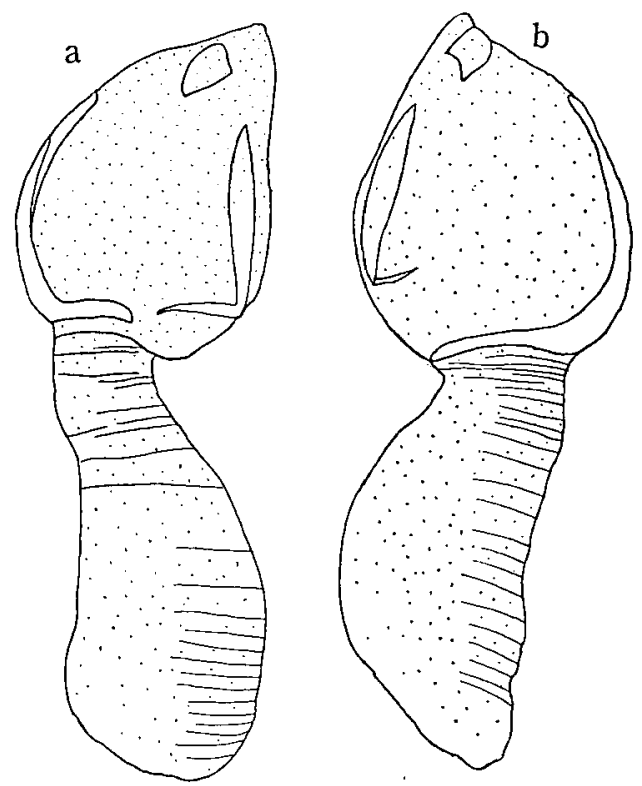

Fig. 1. Octolasmis neptuni (MacDonald), two formae. $(\times 10)$ 
5-6 $\mathrm{mm}$ long; the capitulum $3 \mathrm{~mm}$ long, $2 \mathrm{~mm}$ wide and the peduncle $4 \mathrm{~mm}$ long, $1 \mathrm{~mm}$ wide. The integument is opaque white, transparent and studded with extremely minute, blunt spines all over the surface. Of the five capitular plates, the carina forked at base is the most well calcified, sometimes still chitinized apically (Fig. la). The tergum is varied in form, being either triangular, lunate or bellshaped with slight concave basal margin, but never so saddle-shaped as in the typical Octolasmis lowei (DARwiN). The scutum is L-shaped; the occludent branch is usually wide and calcified, while the shorter basal branch is either chitinous or moderately calcified. When the basal branch is still chitinous and sharply pointed, it is widely separated from the basal fork of the carina. Although Newman (1961) proposed to separate the form with the calcified basal branch of the scutum as ssp. hiroi, it seems to me rather superfluous for the time being, because the degree of chitinization-calcification of valves in such reduced exoskeleton may depend on the growth of individuals living in such less-saline protected habitat as the gill chamber.

\title{
17. Octolasmis angulata (AURIVILliUS, 1893)
}

\author{
forma bullata AURIVILlIUS, 1893 ソリエラエボシ
}

(Fig. 2)

Dichelaspis angulata Aurivillius, 1894, p. 22, pl. II, figs. 9-11; pl. VIII, figs. 1824.

Dichelaspis bullala Aurivilurus, 1894, p. 26, pl. II, figs. 12-13; pl. VI, figs. 10-11; pl. VIII, figs. 19,

Octolasmis angulata (Aurivillius): Nilsson-Cantell, 1934, p. 46, figs. 7-8 (Synonymy).

Octolasmis angulata (Aurivillius): Hiro, 1937, p. 426, figs. 17-18 (Discussion on formae).

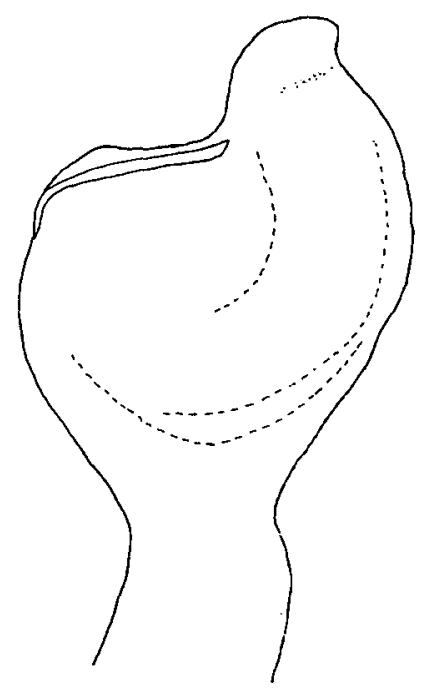

Fig. 2. Octolasmis angulata (AURIviLlius) form: bullata AUR., capitulum. $(\times 9)$ 
Occurrence.-Turuga Bay, Hukui-ken, leg. T. YasudA, 23/IX '66.

Remarks.-The samples were attached to gill lamellae of the swimming crab, Portunus trituberculatus together with the preceding Octolasmis neptuni. They are much larger than the latter, 13-15 mm long and $4 \mathrm{~mm}$ wide (capitulum), so well differentiated. The integument is much bullate, transparent and studded with minute dots. The orifice is protruded like a hood. The scuta situated below the orifice are simply ski-shaped slender plates. There is no trace of the carina at all.

\section{BALANOMORPHA}

\section{Family Chthamalidae (DARWIN) PILSBRY}

18. Chthamalus dalli PILSBRY, 1916 キタイワフジッボ

Occurrence.-Hakodate, leg. M. Tokuda, 18/VII '32 (Hrro, 1932a: 406).

Distribution.- -So far as known, this boreal chthamalid barnacle is not found along the coasts of northern Honsyu, southwards from the Tugaru Strait (UTinomi, 1955).

19. Chthamalus challengeri HoEK, 1897 イワフジッボ

Occurrence.-Hakodate, leg. M. Tokuda, 18/VII '32 (Hiro, 1932; Weltner, 1897: 273 as Ch. stellatus); Osyoro Bay, west Hokkaido, leg. S. Motoda, 29/X '43 (IchikawA and Yamada, 1957: 8); Iwanai and Esasi, west Hokkaido, leg. S. Motoda, 30/X '43; Asamusi, Mutu Bay (Hrro, 1932b: 546; Hiro, 1939a: 207); further southwards.

Distribution.- So far as known, the northern limit of range of this austral chthamalid is Osyoro Bay, west Hokkaido and extends eastwards to Hunka Bay of Hokkaido on the Pacific coast (Utinomi, 1955, p. 119, fig. 2).

\section{Chthamalus pilsbryi HIRO, 1936 オオイワフジツボ}

For description see Hiro, 1936, p. 227 (Seto) and Utinomi, 1954, p. 21 (Tokara Islands).

Occurrence.-Katuma, Sigasima, mouth of Hakata Bay, at highest tide level, leg. Y. MiYa, 13/IX '69.

Distribution.-Restricted to southern Japan as far south as the Tokara Islands.

21. Octomeris sulcata NILSSON-CANTELL, 1932 コウダカキクフジッボ

(Figs. 3-4 and Pl. XVIII, figs. 3-4)

Octomeris sulcata Nilsson-Cantell, 1932, p. 8, figs. 3-4 (Kobe, Japan); Hiro, 1939p, p. 207

(Nezugaseki, Yamagata-ken); Hiro, 1939b, p. 254, figs. 5A, 6C-D (Takau, Taiwan).

Occurrence.-Hutagosima, Asamusi, Mutu Bay, leg. T. HoshiaI, 6/X '63; Nezuga- 
seki, Yamagata-ken, on the shell of Haliotis gigantea, coll. myself, 20/X '35 (Hrro, 1939a: 207); Awasima and Sado Islands, leg. T. KrтAmI, 24/VIII '57, 9/VI '60, 4/VI '67 (Kттам, 1968: 69, fig. 8); interior of marine caves (Grotta) on the Tazima Coast, Hyogo-ken, leg. A. Hosomi, 23/VIII '68 (Hоsoмi, 1966: 26, fig. 2).

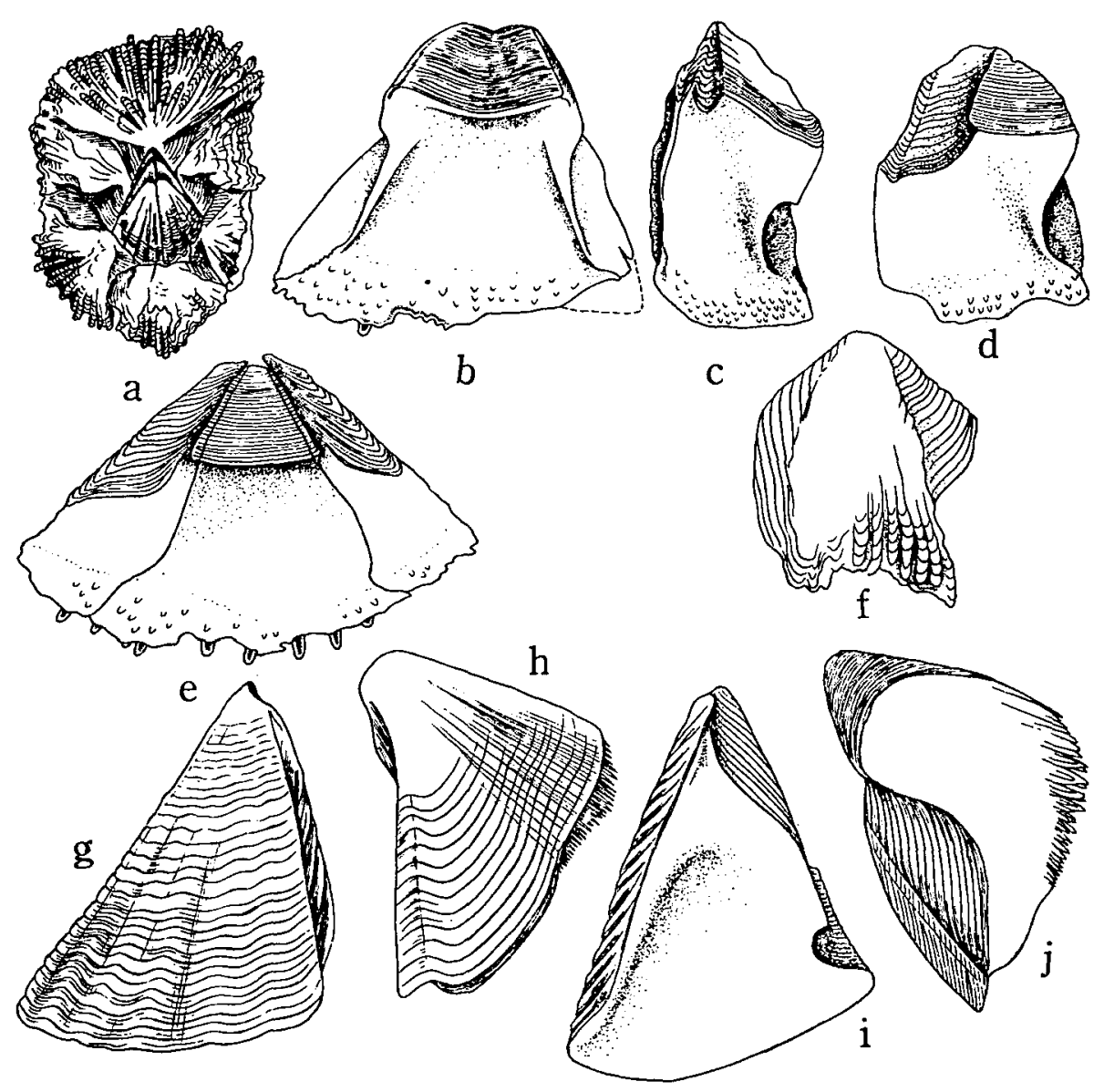

Fig. 3. Octomeris sulcata Nilsson-Cantell from Nezugaseki. $a$, Shell, top view; $b$, carina, inner view; $c$, carino-lateral compartment, inner view; $d$, lateral compartment, inner view; $e$, rostrum and rostrolatera combined together, inner view; $f$, lateral compartment, outer view; $g$, scutum, outer view; $h$, tergum, outer view; $i$, scutum, inner view; $j$, tergum, inner view. $(a \times 8 ; b-j \times 12)$

Distribution.-Grouped on surf-loving rocky reef at the lowest tide level on the warm current washing coasts, from Mutu Bay as far south as Formosan coasts, though occurring locally. 


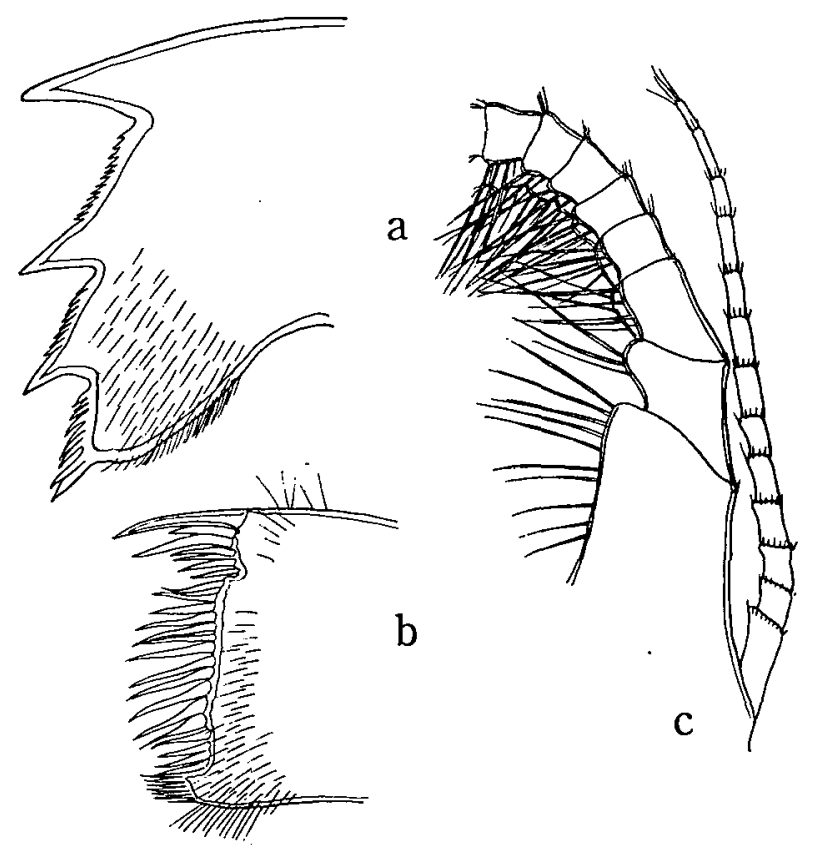

Fig. 4. Octomeris sulcata Nilsson-Gantel. $a$, Mandible; $b$, maxilla $I$; $c$, basal part of last cirrus with a caudal appendage. $(a, b \times 50 ; c \times 16)$

\section{Family Tetraclitidae (NILSSON-CANTELL) RosS}

\section{Tetraclita squamosa japonica PILSBRY, 1916 クロフジッボ}

Occurrence.-Tappi-saki, northermost cape of Tugaru Peninsula, leg. S. Hozawa, 22/VIr '29; Hutagosima, Asamusi, Mutu Bay, leg. S. Hozawa (Hrro, 1939a: 213); Hukaura, Aomori-ken, leg. K. Konno, 20/IX '69; Kuragamura, Akita-ken, leg. S. ONo, 23/VIII '32; Tobi-sima, Hukiura, Kamo and Nezugaseki, all of Yamagata-ken (Suzuki, 1963: 13); Sado and Awasima Islands (KItami, 1968: 70); Hamasaka, Tazima coast, Hyogo-ken, leg. A. Hosom, 10/VIII '66; Yosimi coast of Simonoseki, Yamaguti-ken, leg. Y. MrYa, 9/IX '69; Sigasima, Hukuoka-ken, leg. Y. MrYA, 13/ IX'69.

Distribution.-Common all throughout the west coast as far north as the Cape Tappi-saki, northernmost end of Honsyu.

23. Tetraclitella chinensis (NILSSON-CANTELL, 1921) ムッアナヒラフジッボ (Pl. XVIII, fig. 5)

Tetraclita purpurascens chinensis Nilsson-CANTELl, 1921, p. 359, figs. 81-82, pl. III*, fig. 12 (Hongkong-type locality). 
Tetraclita purpurascens nipponensis HıRo, 1931, p. 155, text-fig. 10, pl. XIV, figs. 3-3d (Seto, Tomioka and Misaki); Hiro, 1932a, p. 473, fig. 5; Hiro, 1937, p. 469.

Tetraclita (Tetraclitella) chinensis (Nilsson-Cantell): Utinomi, 1949, p. 36 (Okinosima, Korea Strait, etc.); Zevina et Tarasov, 1963, p. 97, fig. 14 (Hainan Island, South China on B. tintinnabulum).

Occurrence.-Kitaebisu, Sado Is., Leg. T. KiтAMI, 3/VIII '63, 17/II '67 and 18/IV '67 (Kıтамı, 1968: 70, fig. 18); interior of Zyuzi marine cave, Tazima coast, Hyôgoken, leg. A. Ноsomi, 10/VIII '66 (Hosomi, 1966: 26, fig. 1); Kazumi, Hyôgo-ken, leg. T. Үамамото, 18/VIII '64; Okinosima, Hukuoka-ken, leg. S. Mryake, 14-16/ VII '36; Keya-Oto, Hukuoka-ken, leg. S. Mryake, 28/VII '56; Hanrin, Cheju-Dô Is., Korea Strait, leg. S. OKudA, 14-16/VII '36.

Distribution.-Common from northern Honsyu to southern Taiwan and Hainan Is. of South China at lowest tide level, occurring in sheltered habitat.

\section{Tetraclitella darwini (PILSBRY, 1928) ヨツカドヒラフジッボ}

Tetraclita darwini Pilsbry, 1928, p. 314, fig. 4, pl. 25, fig. 1-3a (Hirado, Kyusyu-type locality). Tetraclita (Tetraclitella) darwini: Hıro, 1939b, p. 277 (Suô, Taiwan).

Occurrence.-Hukaura, Tugaru Region, Aomori-ken, leg. K. Konno, 20/IX '69; Tobi-sima, Yamagata-ken (Suzuki, 1963: 13); Tassya, Sado Is., leg. T. KITAmI, 12/IX '69; Abugasima, Toyama Bay (Hrro, 1939b: 214); Hanrin, Cheju-Dô Is., leg. S. Okuda, 16/VII '36; Sogurpo, Cheju-Dô Is., leg. S. Okuda, 16/VII '36; Hirado, Nagasaki-ken (PILsBry, 1928: 314).

Distribution.-Rarely found on all' Japanese Islands and Korean coast at the lowest tide level in partly protected habitat.

\section{Tetraclitella pilsbryi (UTINOMI, 1962) フルイヒラフジッボ(新称)}

(Fig. 5)

Tetraclita (Tetraclitella) pilsbryi Uтімомт, 1962, p. 234, figs. 11-12 (Nomosaki, Nagasaki-ken-type locality).

Occurrence.-Off Maizuru, Wakasa Bay, leg. Sh. Fuse, VI '67, on the living shell of Batillus cornutus, together with B. trigonus; Sigasima, mouth of Hakata Bay, leg. Y. Mrya, 13/IX '69, on the shell of Batillus cornutus.

Distribution.-Hitherto found also from Cape Asizuri-saki, southwest of Tosa Bay, Sikoku on the under surface of corallum of the reef coral Symphyllia recta (DANA), leg. Sh. Fuse, 1966 (unpublished). From these collecting data, this tetraclitellid seems to inhabit in the lowest tide level or the upper subtidal area in southern Japan only.

Remarks.-Superficially this species is hardly distinguishable from Balanus trigonus and Octomeris sulcata in the ribbed ornamentation of the shell, but distinguisuable from them often occurring together by examining the wall structure at the bottom. 
Formerly I (HrRo, 1939b) established Tetraclitella for the depressed forms of Tetraclita ( $T$. purpurascens and its allies) as a subgenus of Tetraclita Schumacher. Another subgenus Tesseropora PILSBRy (1916) is maintainable for the species of Tetraclita whose wall is conical in shape, but internally formed of a 'single layer of square or squarish parietal tubes'. In ordinary Tetraclitas parietal tubes are often one-layered and provided with secondary tubes or denticles inside the outer lamina in younger stages, as discussed already by Darwin (1854) and Henry (1957). Therefore, the growth and arrangement of parietal tubes of the wall reflect the intergradation from Tesseropora-stage to Tetraclita-stage. In the case of Tetraclitella, however, the parietal tubes are uniformly small, non-septate, cylindrical and then radially arranged from the apex of the parietes to the sides of the radii and alae during all stages of growth. The habitat is also peculiar, being mostly hypobiotic in the
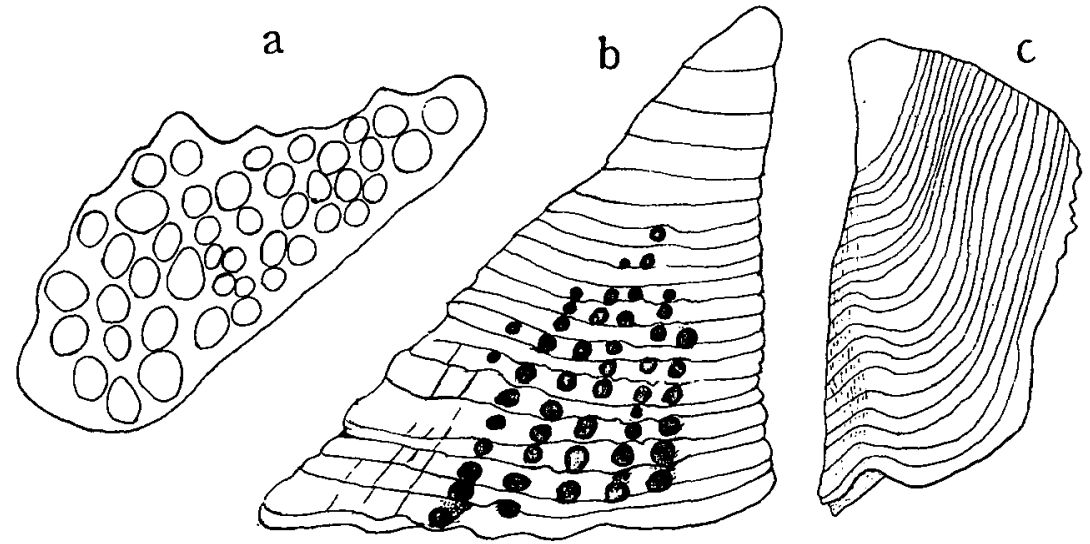

Fig. 5. Tetraclitella pilsbryi (Uтімомі) from off Maizuru. $a$, Section of lateral compartment; $b$, scutum, outer view; $c$, tergum, outer view. $(a-c \times 11)$

lower littoral and the distribution is mostly circumtropical. For these reasons Tetraclitella is to be raised to the generic rank for the present, inasmch as the familial level of the Tetraclitidae (Nilsson-Cantell as subfamily) is duly warranted (Ross, 1968).

\section{Family Balanidae (LEACH) DARWIN}

\section{Subfamily Balaninae DARWIN}

26. Balanus (Megabalanus) tintinnabulum rosa PILSBRY, 1916

$$
\text { アカフジッボ }
$$

(Pl. XVIII, fig. 7)

Occurrence.-Hutagozima, Asamusi (Hrro, 1932b: 549); Tappisaki, Aomori-ken; Hukaura, Aomori-ken, leg. K. KonNo, 20/IX '69; Hunakawa, Akita-ken (Hrro, 
1939a: 208); Tobisima and Nezugaseki, Yamagata-ken (Suzuki, 1963: 13); Sado and Awasima Islands (Krтamr, 1968: 69); Usetu, Toyama Bay, Isikawa-ken, leg. K. Suzukı, 6/VII '68; Tôzinbô, Hukui-ken (Hiro, 1939a: 208); Turuga Bay, Hukuiken (Mawatari, 1967: 99); Kodomari Hukui-ken, leg. T. Yasuda, 31/VII '68; Maizuru Bay, leg. Sh. Fuse, VI '67; Kazumi, Tazima coast, Hyôgo-ken, leg. T. Yamamoto, 18-19/VIII '64; Iwami, Tottori-ken, leg. T. Yamamoto, 18/VIII '64; Sakai Port, Simane-ken, leg. T. IgA, 8/VIII '68; Uragô, Nisinosima, Oki Island, leg. T. Yамамото, 26/VIII '64; Iki Island, leg. Zool. Inst., Tokyo Univ., '49; Tuyasaki, Hukuoka-ken, leg. Y. Dotsu, 6/VI '56; Sigasima, Hukuoka-ken, leg. Y. MrYA, 13/IX '69.

Distribution.-So far as known this well-known barnacle has not been recorded from Hokkaido. Thus its northern limit of range is the Mutu Bay.

\section{Balanus (Megabalanus) tintinnabulum volcano PILSBRY, 1916}

オオアカフジツボ

(P1. XVIII, fig. 6)

Occurrence.-Sado and Awasima Islands, leg. T. Kitami, 9/VI '60 (Kitami, 1968: 69, fig. 10); Tôzinbô, Hukui-ken (Hrro, 1939a: 208); Hirata, east of Hinomisaki Cape, Simane-ken, leg. T. IGA, VIII '68.

Distribution.-Rather occasionally found along the Japan-Sea coast, probably due to the poorness of adequate substrata or hydrographical condition for this surfloving upper subtidal barnacle. Awasima is thus the northern limit of its known range.

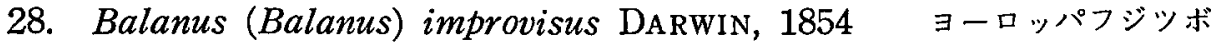

(Figs. 6-7)

Balanus improvisus Darwin, 1854, p. 250, pl. 6, figs. 1a-1c (with var. assimilis); Pilsbry, 1916, p. 84, pl. 24, figs. 3-3b, 5-5d, text-figs. 16A and 17; Nilsson-Cantell, 1921, p. 310; Tarasov and Zevina, 1957, p. 168, figs. 58-60; Utinomi, 1968, p. 171; Mawatari et al., 1968, pl. V, fig. M-R. ?Balanus amphitrite vladivostokensis TARAsov and ZEvina, 1957, p. 184, fig. 67 (Vladivostok).

Occurrence.-Kodomari, east of Utiura Cove, Wakasa Bay, leg. T. YASUdA, $29 /$ III '68; Otomi in Utiura Cove, Wakasa Bay, attached to celluloid fouling testpanels, 5-9 m deep, leg. T. Yasuda, 30/IV '68; Sakai Port and Esima in Lake Nakaumi and Matue, entrance to Lake Sinzi-ko, leg. T. IGA, 8/VIII, 30/XI '68; Brackish lake Zinzai-ko, Simane-ken, leg. T. KAmitA, 5/VIII '68.

Distribution.-This well-known Atlantic brackish water barnacle had not been recorded from the oriental waters before the World War II. It has invaded into the Pacific coasts of southern Japan in recent years (KAWAHARA, 1963; Utinomi, 1966; Mawatari, 1967; Mawatari et al., 1968). 
As shown above, this species was recorded for the first time from the Ise Bay on the Pacific coast of Japan. It shows two distributional patterns on the Japan-Sea coast, namely Izumo Region and Wakasa Bay, but it does not yet extend further northwards.

Remarks.-All shells newly settled on fouling test-panels set in Utiura Cove of

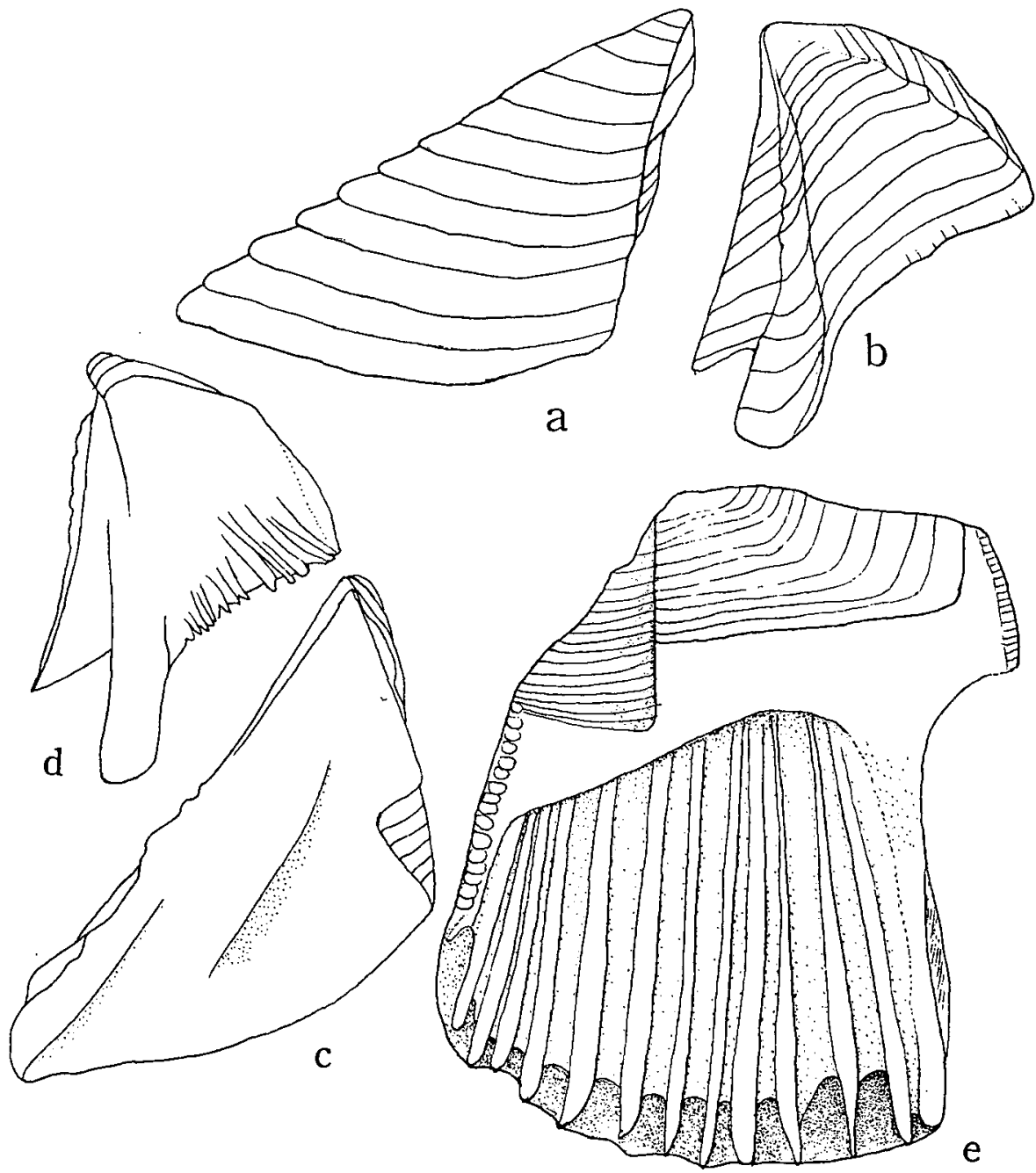

Fig. 6. Balanus improvisus DARwin from Utiura Cove. $a$, Scutum, outer view; $b$, tergum, outer view; $c$, scutum, inner view; $d$, tergum, inner view; $e$, lateral compartment, inner view. $(a-e \times 12)$

the southern coast of Wakasa Bay are conical or tubular in form, snowy white and covered with a slightly purplish brown membrane. The alae are broad, with roundly curved apex and the radii are medium in width and obliquely curved marginally. As shown in Fig. 6e, the detailed parietal structure is similar to that of other species 
in $B$. amphitrite-series, but there is no secondary riblets or teeth between the internal ribs towards the base of the outer lamina (though present in B. eburneus).

The scutum is slightly convex outside and provided only with widely spaced growth ridges; internally the depressions for adductor and depressor muscles are

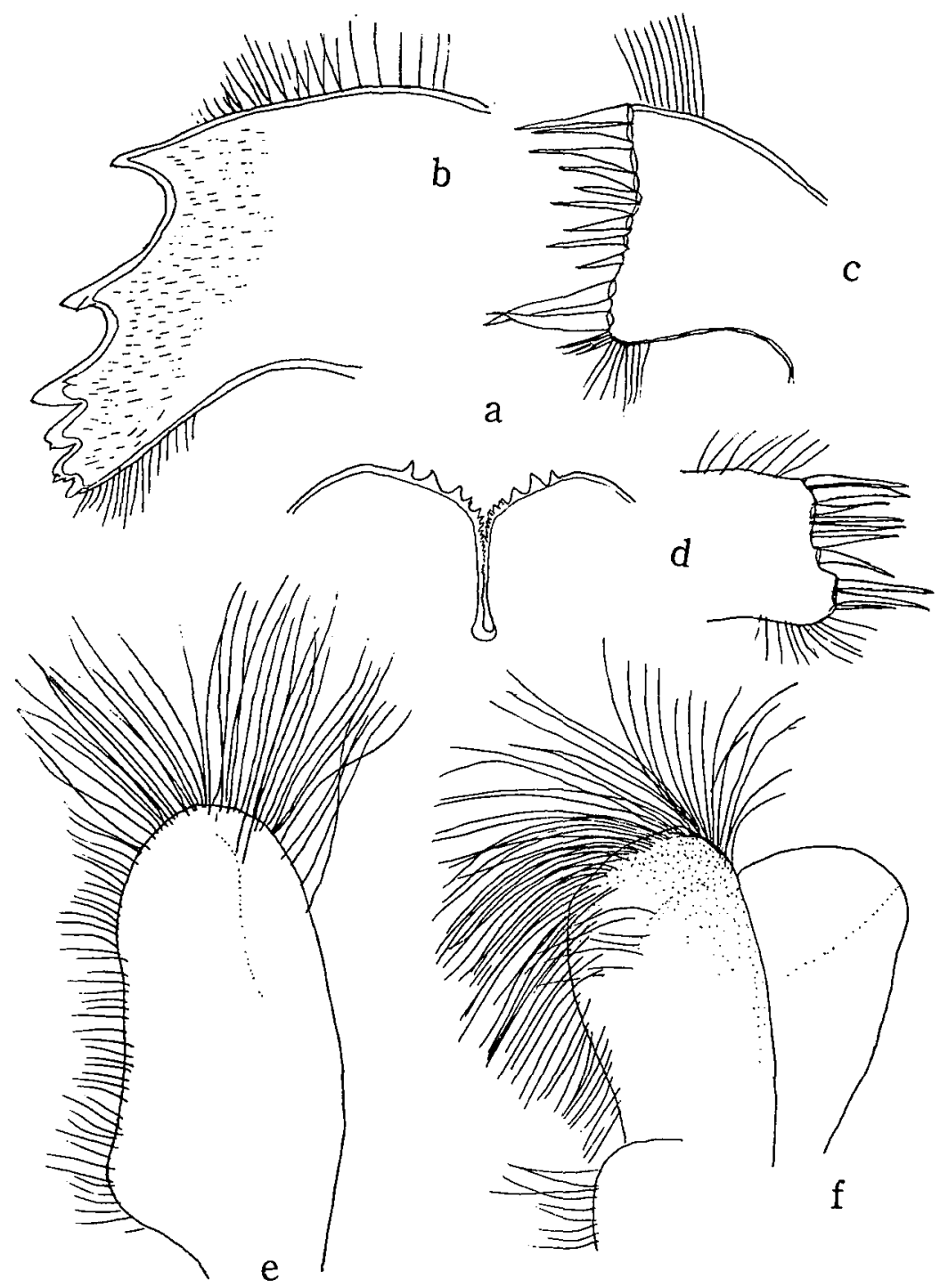

Fig. 7. Balanus improvisus DARwIN from Utiura Cove. $a$. Labrum; $b$, mandible; $c$, $d$. maxilla I; $e$, palp; $f$, maxilla II. $(a, e, f \times 43 ; b-d \times 53)$

generally obscure. The tergum is triangular, with a distinctly furrowed, narrow, long or medium, spur and many crests for depressor muscles all along the basal margin. 
These opercular peculiarities are shared by $B$. amphitrite vladivostokensis briefly described with only a figure of opercular valves by TARAsov and Zevina (1957) from Vladivostok in the pre-war time. For the present $I$ am inclined to feel them as synonymous.

\section{Balanus (Balanus) eburneus GouLD, 1841 アメリカフジッボ}

(Pl. I, figs. 8-10; Text-figs. 8-9)

Balanus eburneus Gould, 1841, p. 15, pl. I, fig. 6; DARWin, 1854, p. 248, pl. 5, figs. 4a-4d; WeLTNER, 1897, p. 226; Pilsbry, 1916, p. 80, text-figs. 14-15, pl. 24, figs. 1-1c, 2; TARasov and Zevina, 1957, p. 174, fig. 61; Nilsson-Cantell, 1938, p. 35; Matsui, Shane and Newman, 1964, p. 141, fig. 1 (Hawaii); Utinomi, 1966, p. 36, fig. 1 (Sado); Mawatari, 1967, p. 99.

Occurrence.-Kamo, Yamagata-ken, leg. M. InABA, X '64 (Utinomi, 1966: 38); Brackish lake Kamo-ko, Sado Island, on test-panels and bamboo set on an oyster

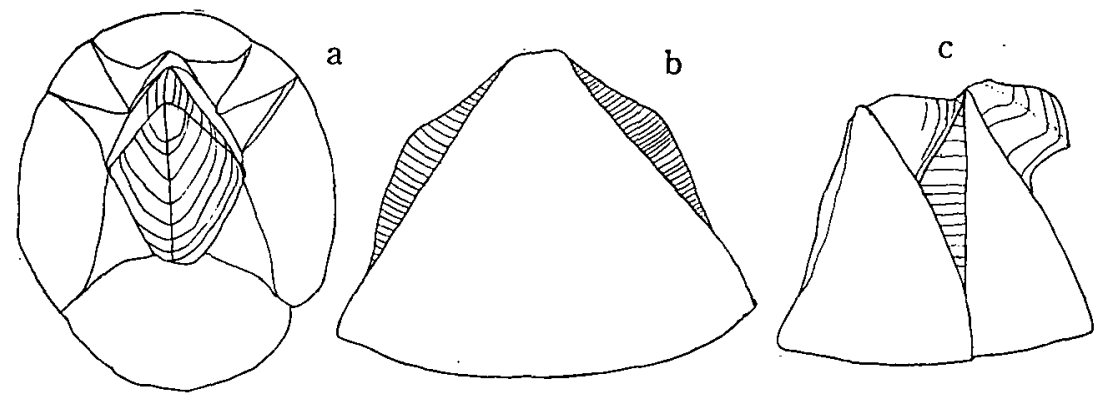

Fig. 8. Balanus eburneus Gould from Utiura Cove, newly settled young. $a$, Newly settled young, $3 \mathrm{~mm}$ wide, top view; $b$, rostrum, outer view; $c$, carino-lateral and lateral compartments connected together. $(b-c \times 9)$

farm, leg. T. Kiтami, 11/I '66 (Utinomi, 1966: 36; Kitami, 1968: 69); Ryôtu Port, Sado Is., on buoys, leg. H. SAKaI, 15/IX '68; Turuga and Maizuru, Wakasa Bay, on fouling aluminium test-panels, leg. Mawatari and H. Kitamura, V-VII '65 (Mawatari, 1968: 99); Otomi in Utiura Cove, on fouling celluloid test-panels, leg. T. Yasuda, 27/VI-3/VII '68; Kodomari, east of Utiura Cove, leg. T. YAsuda, 31/ VII-24/X '68; Sigasima, hull of fishing boats, leg. Y. MiYA, 13/IX '69; Hakozaki Pier, Hukuoka, Hakata Bay, leg. Y. Mrya and T. Arita, 25/IX '69.

Distribution.-This recent immigrant from the American Atlantic coast has firstly recorded from a brackish lake Kamo-ko in Sado Is. in the Japan Sea (Utinomi, 1966). As far as I have confirmed materially, it has hitherto been found in Nagasaki and Sasebo ports in western Kyusyu and Hirosima and Kure ports in Seto Inland Sea on the Pacific coast. It is probable that this barnacle has invaded into Japanese waters by the transport of American ships successively increased after the World War II and enhanced by the influence of the warm Tusima Current washing the 
western coasts of Japan (Utrixomi, 1966; Matsui, Shane and Newman, 1964).

Remarks.-The shell is snowy white like the above-mentioned B. improvisus, but easily distinguished by having the wider radii closely attached to the parietes of the adjoining plates. The parietal tubes are also one-layered, large and transversely septate to the base and there are many riblets towards the base within the parietal tubes.
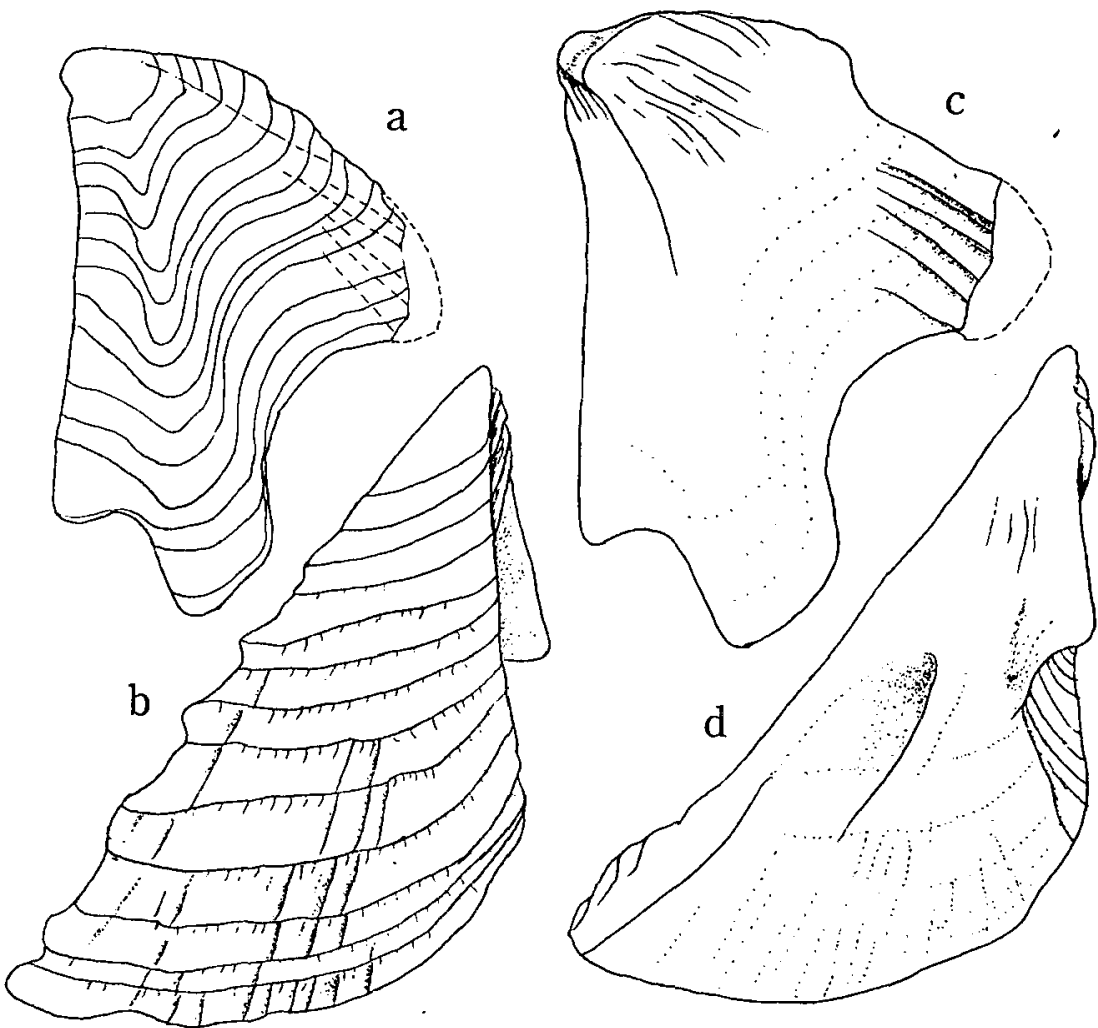

Fig. 9. Balanus eburneus Gould from Utiura Cove, newly settled young. a, Tergum, outer view; $b$, scutum, outer view; $c$, tergum, inner view; $d$, scutum, inner view. $(a-d \times 29)$

The scutum has externally many longitudinal striae or ridges crossing with the widely spaced growth ridges which are fringed with hairs at younger stages. The tergum is broader than that of $B$. improvisus, without longitudinal striation. The carinal margin of the tergum is highly arched and often ledged in the upper half. Its basal corner is roundly protruded and provided with several long crests for depressor muscles inside. The spur is broad and truncated at the end like a shovel. The basal margin between the spur and carino-basal projection is deeply excavated.

Besides, a prominent peculiarity of this species to distinguish from $B$. improvisus 
is that the maxilla $I$ has a series of comb-like smaller spines between the upper and lower simple larger spines along the frontal edge.

\section{Balanus (Balanus) amphitrite amphitrite DARWIN タテジマフジッボ}

For synonymy and description see Uтinomi, 1967, p. 200, pl. VI, fig. 1.

Occurrence.-Hakodate, Hokkaido (Mawatari, 1967: 99); Ominato, Mutu Bay (Mawatari, 1967: 99); Awasima and Sado Is., 0-10 m (Kitami, 1968: 70, fig. 12); Turuga Bay (Mawatari, 1967: 59); Nyû-ura, west of Turuga Bay (Yasuda, 1968: 27); Kodomari, east of Utiura Cove, Hukui-ken, leg. T. Yasuda, 31/VII '68; Maizuru Bay, on rocky reef, leg. Y. Yamamoto, 22/VI '69; Kazumi, Hyôgo-ken, leg. T. YAMAмото, 19/VIII '64; Sakai Port, Simane-ken, on anchor, leg. T. IGA, 4/XII '68; Yosimi, Simonoseki, Yamaguti-ken, leg. Y. MrYa, 9/IX '69; Hakozaki and Nazima in Hakata Bay, leg. T. Arita, 18/IX '69.

Distribution.-Widely distributed as north as Mutu Bay and Tugaru Strait, mostly occurring on intertidal or upper subtidal stones, rocks or moles in quiet bays protected from rough surf.

\section{Balanus (Balanus) venustus venustus DARWIN アカシマフジッボ(新称)}

$$
\text { (Pl. XVIII, fig. 11) }
$$

For synonymy and description see Stubbings, 1967, p. 280, figs. 17-18.

Occurrence.-Tassya, Aikawa, Sado Is., leg. T. KiтAмI, 24/VIII '68; Otomi in Utiura Cove, juveniles newly settled on fouling test-panels, leg. T. YAsuda, 28/V '69.

Remarks.-A sample from Tassya, Sado Is. is a well developed adult, $21 \mathrm{~mm}$ in carino-rostral diameter, about $1 / 3$ as large as the base. The parietes are quite smooth, polished pinkish white and ornamented with evenly spaced narrow bright pink stripes longitudinally, about 40 in all (2 in carinolateral, 10 in lateral and carina, and 15 in rostrum). The radii are broad with horizontal apex, colored pink darkly upwards. In a young sample (4.6 $\mathrm{mm}$ in carino-rostral diameter) newly settled on fouling test panels at Otomi in Utiura Cove, pink stripes count 3 in carinolateral and 11 in carina, lateral and rostrum respectively.

The radii are broad, bright pink and transversely septate. The parietal tubes are large, transversely septate upwards and only 2 riblets are inserted at base on the inner surface of the outer lamina. The inner surface of the opercular valves is more or less beaded or striated radially upwards. The tergum is flat, triangular, with a short, broad spur, about $1 / 3$ the width of the basal margin, slightly separated from the basi-scutal angle.

This beautiful barnacle may have been confused with the similarly sized roseate 
form B. tintinnabulum rosa, often occurring together.

In the post-war time I have occasionally obtained this species from the hulls of over-sea going vessels returned from West Africa or Kwait, but never found actually from the Japanese coasts. Therefore, this is evidently a new addition to the fauna of Japan actually as colonized very recently.

\section{Balanus (Balanus) reticulatus UTINOMI, 1967 サラサフジッボ}

For synonymy and description see Utinomi, 1967, p. 216, text-figs. 9-12 and pl. VI, figs. 7-8.

Occurrence.-Maizuru Bay, from the hull of navy ships' bottoms, leg. T. SArto, 24/II '38 (SAIto, 1929: 7, fig. 1-1, as B. amph. niveus); Nokozima in Hakata Bay, on stranded bamboo, leg. Y. Mrya, 10/X '69.

Distribution.-Probably widespread in the world. In the pre-war time, this barnacle was predominant rather than $B$. amphitrite of fouling barnacles in Japanese bays and harbors, but now apparently not found on the Japan-Sea coast (cf. MAWATARI, 1967). Occurring in stenohaline habitats only.

\section{Balanus (Balanus) uliginosus UTINOMI, 1967 ドロフジッボ}

For the synonymy and description see Utinomi, 1967, p. 202, text-figs. 1-2, pl. VI, figs. 4-6.

Occurrence.-Esima in Nakaumi Lake, on buoys of anchors, leg. T. IGA, 30/XI '68; Yosu, southern Korea, leg. S. OKudA, 12/VII '36; Mokpo, southern Korea, leg. S. Okuda, 10/VII '36; Gônoura, Iki Is., leg. Zool. Inst. Tokyo Univ. (Hiro, 1938: 305).

Distribution.-Hitherto known only from southern Japan, southern Korea, China and Taiwan, usually occurring on various things set on muddy bed in lesssaline quiet bays at the lowest tide level.

\section{Balanus (Balanus) albicostatus albicostatus PILSBRY, 1916 シロスジフジッボ}

For the synonymy and description see Utinom, 1967, p. 209, text-figs. 4-5, pl. IV, fig. 2.

Occurrence.-Asamusi, Mutu Bay (Hiro, 1939a: 209); Ominato, Mutu Bay (Mawatari, 1967: 99); Tobisima and Nezugaseki, Yamagata-ken (Suzuki, 1963: 13); Ryôzu Port and Kamo-ko Lake in Sado Is. (Krtami, 1968: 70, fig. 13); Sakai Port, Simane-ken, leg. T. IGA, 30/XI '68; Pusan, southern Korea, leg. S. OxudA, 2/VIII '36; Kunsan, southwestern Korea, leg. S. OkudA, 10/VII 36; Cheju-Dô Is., Korea Strait, leg. S. Okuda, 14/VII '36 (Hiro, 1938: 303); Okino-sima, Tusima Strait, leg. S. Mryake, 14-18/X '32, 19-29/V '33 (Hrro, 1938: 304; Utinomi, 1949: 
22); Yosimi, Simonoseki, leg. Y. MrYA, 9/IX '69; Nazima in Hakata Bay, leg. T. ARITA, 18/IX '69.

Distribution.-Prevalent on intertidal rock, wharf piles and other harbor installations in bays, as far north as Mutu Bay.

\section{Balanus (Balanus) variegatus cirratus DARWIN, 1854 アミメフジッボ}

For synonymy and description see Utinomi, 1967, p. 214, text-fig. 8.

Occurrence.-Gônoura, Iki Is., Tusima Strait, on stranded bamboo, leg. M. Tokuda, III '37; (Hrro, 1938: 303; Utrnomi, 1949: 22); Yosimi, Simonoseki, on submerged concrete block, leg. Y. MrYa, 9/IX '69; Koga Beach, Hukuoka-ken, leg. S. OYogi, 20/IX '69.

Distribution.-Hitherto recorded from Australia, Indian Coast, Singapore, Malay Archipelago, Philippines, Taiwan, China, northwestern Korea and western Kyusyu (Zevina and Tarasov, 1963, p. 91; Utinomi, 1967, p. 216). Other records from Japan need further confirmation.

\section{Balanus (Balanus) trigonus DARWIN, 1854 サンカクフジッボ}

Occurrence.-Mutu Bay (Hrro, 1932b: 551; Hrro, 1939a: 210); Tappi-saki, Tugaru Pen. (Hrro, 1939a: 210); Nezugaseki, Yamagata-ken (Suzukı, 1963: 13); Sado Is. (Kitami, 1968: 70, fig. 14); Toyama Bay and Turuga Bay (Hrro, 1939a: 210; Mawatari, 1967: 59); Turuga, Kodomari and Otomi, Hukui-ken, on fouling test panels, 0-13 m, leg. T. YAsuda, 24/X '68; Maizuru, on the shell of Batillus cornutus, leg. Sh. Fuse, VI '67; Kazumi, Hyogo-ken, on the shell of Mytilus coruscus, leg. T. Yамамото, 26/VIII '64; Iwami, Hyôgo-ken, leg. T. Yамамотọ, 19/VIII '64; Moroyose, Hyôgo-ken, leg. S. Nishimura, 28/V '69; Karo, Tottori-ken, leg. T. Yамамото, 26/VIII '64; Sakai Port, on anchors and ropes, leg. T. IgA, 8/VIII '68; Nahisa, Dôgo, Oki Is., leg. T. Yамамото, 23/VIII '64; Kurokigosyo, Oki Is., leg. T. Yамамото, 26/VIII, '64; Marutani, Oki Is., leg. T. Yамамото, 26/VIII '64; Iki Is., on stranded bamboo (Utinomi, 1949: 22); Okinosima, Tusima Strait (Utinomi, 1949: 22); Yosimi, Simonoseki, leg. Y. MrYa, 9/IX '69; Sigasima, leg. Y. MrYA, 13/IX 69; Tuyasaki, Hukuoka-ken, leg. Y. Dôtsu, 6/VI '56; Koga, leg. S. OYoGr, 20/IX '69; Nokozima in Hakata Bay, leg. Y. Mrya, 10/x '69.

Distribution.-Cosmopolitan, usually on various things in the subtidal zone.

\section{Balanus (Balanus) rostratus HoEK, 1883 ミネフジッボ}

Occurrence.-Off Siriyazaki, Tugaru Strait (Sôyô-maru Benthic Survey Station 76, 41 ${ }^{\circ} 11^{\prime} 30^{\prime \prime} \mathrm{N}, 141^{\circ} 28^{\prime} 45^{\prime \prime} \mathrm{E}, 128 \mathrm{~m}$ ) (Hrro, 1933: 71); Hakodate, Hokkaido 
(Weltner, 1897: 268 as B. porcatus; Hiro, 1935: 217); Asamusi, Mutu Bay (Hrro, 1933: 551; Hrro, 1939a: 210); Tassya, Aikawa, Sado Is., youngs on glass buoys, leg. T. Kitami, 25/VI '67 (Kiтамi, 1968: 70, fig. 15, as 'B. rostoratus'); Usetu, Isikawaken, Toyama Bay, young on Octopus pot, leg. K. SuzukI, 6/VII '68; Noto, Isikawa-ken, Toyama Bay, youngs on the shell of Pomgaulax japonicus, leg. K. SuzukI, VI '65; Kanaisi, near Kanazawa City, Isikawa-ken, youngs on the shell of Pugilina ternatana, leg. K. SuzukI, 15/XI '68; Tusima Strait (Sôyô-maru Benthic Survey

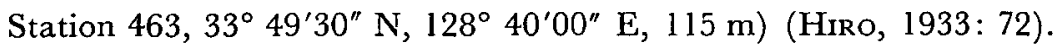

Distribution.-Widely distributed in northern Japan (usually Hokkaido, Sanriku Coast, Sagami Bay and deep basin of Seto Inland Sea). On the west coast of northern Honsyu washed by the warm Tusima Current, this barnacle is rarely found on benthic animals or things in the subtidal zone and small-sized.

\section{Balanus (Balanus) crenatus BRUGUIÈRE, 1789 ハナフジッボ}

For synonymy and description see Prlsbry, 1916, p. 165, pls. 39-40 and Hiro, 1935, p. 219, pl. X, fig. 4 and text-fig. 2 .

Occurrence.-Osyoro Bay, Hokkaido, leg. S. Motoda, 29/IX '43 (Ichikawa and YAMADA, 1957: 8); Nezugaseki, Yamagata-ken, on the shell of Pugilina ternatana and Phalium strigatum, dredged, leg. Sh. Suzuki, '58 (Suzuki, 1963: 13).

Distribution.-Although this is an amphiboreal species occurring in northcast and southeast coast of Hokkaido, it is not found on the Pacific coast of northern Honsyu but curiously it penetrates far southwards to the south of the Gotô Islands, western Kyusyu (Utinomi, 1968, pp. 24, 26) and to Santuao, Tokien, South China (NrlssonCantell, 1925, p. 113).

\section{Balanus (Semibalanus) cariosus (PALLAS, 1788) チシマフジッボ}

For synonymy and description see PilsBry, 1916, p. 189, pl. 46, pl. 47, figs. 1-1c and Hiro, 1932a, p. 472 , fig. 3 and Hiro, 1935, p. 223, pl. X, fig. 3 and text-fig. 4.

Occurrence.-Osyoro Bay, Hokkaido, leg. T. Uchida, VIII '34 and leg. S. Motoda, 29/x '43 (Hiro, 1935: 223; Ichikawa and Yamada, 1957: 8); Hakodate, Tugaru Strait (Weltner, 1897: 270).

Distribution.-Ganadian coast south to Oregon and westwards to Alaska, Kuril Islands (type locality), Hokkaido and Sanriku Coast of northern Honsyu as far south as Matusima Bay (Hiro, 1939; Utinomi, 1955, p. 119, fig. 2). Along the west coast of northern Honsyu, it is not found. According to TaRasov and Zevina (1957, p. 215), it occurs rather rarely on the Maritime coast of Soviet Russia south to Chongjin, North Korea. 
40. Balanus (Solidobalanus) hesperius PILSBRY, 1906

アラスカフジッボ (新称)

For description see PilsBry, 1916, p. 193, text-figs. 60-61, pl. 49, figs. 1-1d, 7-7b, 8 and Hiro, 1935, p. 225 , fig. 5.

Occurrence.-Kugurizaka near Asamusi, Mutu Bay, on the shell of Fulgoraria rupestris inhabited by a hermit crab and 2 other localities in the same bay (HrRo, 1939a: 212).

Distribution.-Alaska, Bering Sea, British Columbia, Kurile Islands, Hokkaido, Saghalin. Subspecies nipponensis PILsBry is recorded southwards from off Daikokusaki (? Bôsô Peninsula).

41. Balanus (Solidobalanus) socialis HoEK, 1883 ムレフジッボ

For synonymy and description see Hiro, 1937, p. 442, fig. 26 (off Tanabe Bay).

Occurrence.-Ryôtu, Sado Is., on the shell of Batillus cornutus, leg. M. TokudA, 18/VII '32 (Hrro, 1932a: 473, fig. 4 as Balanus sp. undet.); NNE 10 miles off Niigata Port, $35 \mathrm{~m}$ deep muddy botom, attached in group on a human skull, obtained by trawl-net in June of 1961 (Koseki and Yamanouchi, 1962: 295, fig. 4; Kitami, 1968: 70, fig. 16; Honma, 1968: 35, fig. 7; all listed only).

Distribution.-Southern Japan (Kii district, western Kyusyu), Malay Archipelago, Bay of Bengal and Iranian Gulf, occurring on benthic animals living on soft bottom, about $10-50 \mathrm{~m}$ in depth.

42. Balanus (Conopea) granulatus HIRO, 1937 ウミカラマッフジッボ

Occurrence.--Off Noto-saruyama, Isikawa-ken, $90 \mathrm{~m}$, on Antipathes japonica, $90 \mathrm{~m}$, leg. K. Suzuki, 9/IX '65.

Distribution.-Southern Japan, on antipatharians.

43. Acasta japonica PILSBRY, 1906 ヤマトカイメンフジッボ For synonymy and description see UтіNoмI, 1962, p. 221, figs. 3-4.

Occurrence.-Toyama Bay, leg. K. Kiкuchi (Hiro, 1939a: 213).

Distribution.- Rarely recorded from Japanese and Malayan waters, inhabiting in silicious sponges.

\section{Subfamily Chelonibiinae PILSBRY}

\section{Chelonibia testudinaria (LINNÉ, 1758) カメフジッボ}

For synonymy and description see Pilsbry, 1916, p. 264, pl. 62, figs. 1-4 and Hiro, 1937, p. 470, fig. 41 . 
Occurrence.-Kamo and Nezugaseki, Yamagata-ken (Suzukı, 1963: 13); Tassya, Aikawa, Sado Is., on the carapace of Caretta caretta (KITAmI, 1968: 70, fig. 19); Toyama Bay (Hrro, 1939a: 214); Hakata Bay (Utinomi, 1949: 24).

Distribution.-All tropical and subtropical seas, on sea-turtles.

\section{Subfamily Coronulinae (LeAch) PILSBry}

\section{Platylepas hexastylos (O. FABRICIUS, 1798) サラフジッボ}

For synonymy and description see PILsBry, 1916, p. 285, pl.67, figs. 1-1c, 3 and Hiro, 1937, p. 472, fig. 43.

Occurrence.-Tassya, Aikawa, Sado Is., on the carapace of Caretta caretta and Dermochelys coriacea, leg. T. KIтAmI, 14/VIII '66 and 14/II '69 (KIтAmI, 1968: 71, fig. 20); Hakui, west of Noto Pen., Isikawa-ken, on the carapace of Dermochelys coriacea, leg. T. Suzuki, 2/II '66; off Cape Kyôga-misaki, west of Wakasa Bay, on the carapace of Dermochelys coriacea, leg. T. YASUdA, 28/II '68.

Distribution.-All tropical and subtropical seas, on turtles, manatees and dugong. A variety on Lepisosteus.

\section{Platylepas ophiophila LANCHESTER, 1902 ウミヘビフジッボ(新称)}

(Text-figs. 10-11; Pl. XVIII, figs. 12-15)

?Plalylepas-? Darwin, 1854, p. 430 (Imbedded in the skin of a seasnake from off Borneo).

Platylepas ophiophilus Lanchester, 1902, p. 371, pl. 35, figs. 5-5b (Imbedded in the skin of the seasnake, Enhydrus curtus from an unknown locality of the Malay Peninsula).

Platylepas ophiophilus Lanchester: Gruvel, 1905, p. 277, fig. 301 bis, A and B (Reproduced only from LANCHESTER, 1902).

Cryptolepas ophiophilus KRÜGer, 1912, p. 12, pl. 3, figs. 7-8 (Attached to the tail of a sea-snake Hydrophis (?) gracilis (?) from Gwadar, Baldschistan (=Baluchistan), Arabian Sea).

Plalylepas krügeri PILSBRY, 1916, p. 285 (Renamed for KRÜGer's Cryptolepas ophiophilus, without new locality).

PPlatylepas decorala Darwin: Nilsson-Cantell, 1921, p. 376, fig. 89 (On the sea-snake from the east coast of Australia).

Platylepas krügeri Pilsbry (?): BRoCH, 1931, p. 122 (On Enhydris hardwicki (GRAY) from $1^{\circ}-2^{\circ} \mathrm{S}$, $105^{\circ}-107^{\circ} \mathrm{E}$, between Sumatra and Borneo Islands.)

Platylepas ophiopholis (sic) Lanch.: Nilsson-Cantell, 1938, p. 77 (On the sea-snake Enhydrina valakadyn (BoIE) from Karachi and from Ganjam Coast, Madras Presidency, India).

Occurrence.-Imbedded in the skin of a large sea-snake Hydrophis cyanocinctus Daudin stranded at Kodatu Beach in Mano Bay on the west coast of Sado Island captured by T. Kiтami on December 11, 1965 (KIтAmi, 1968: 71, fig. 21 as Platylepas krugeri PiLs.).

Description.-About 50 complete specimens were obtained from the sea-snake Hydrophis cyanocinctus Daudin (about $110 \mathrm{~mm}$ long). Some of them preserved for the museum collection are measured as follows: 


\begin{tabular}{lcllc}
\multicolumn{1}{c}{ Outline } & $\begin{array}{c}\text { Carino-rost. } \\
\text { diam. }\end{array}$ & $\begin{array}{c}\text { Lateral } \\
\text { diam. }\end{array}$ & Height & Orificial diam. \\
ovoid & $9 \mathrm{~mm}$ & $6 \mathrm{~mm}$ & $4 \mathrm{~mm}$ & $5 \mathrm{~mm}$ \\
ovoid & 7.5 & 4.0 & 4.0 & partly damaged \\
hexagonal & 6.4 & 4.0 & 2.5 & 4.0 \\
ovoid & 6.2 & 5.0 & 2.5 & 4.1 \\
hexagonal & 6.0 & 5.2 & 2.5 & 4.0
\end{tabular}

It is very difficult to obtain any good intact specimens technically, as they are wholly covered with the chitinous membrane of the snake's skin, tightly fitting together with the ribbed ornamentation over the compartments.

The wall is subconical, not so depressed as that of $P l$. hexastylos. The outer surface of the wall fully denuded is longitudinally ribbed, crossing by transverse

a
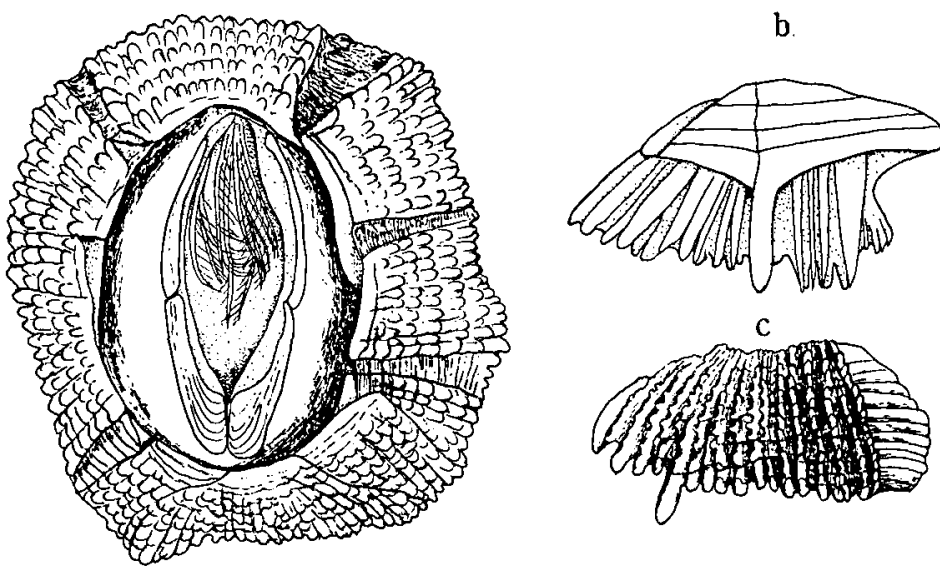

Fig. 10. Platylepas ophiophila LANchester from Mano Bay, Sado Is. a, Animal, top 'view; $b$, lateral compartment, inner view; $c$, lateral compartment, outer view. $(a \times 8.5 ; b, c \times 16)$

grooves (or growth annuli) and the ribs are profusely beaded or spinose along the annuli, just like the valves of Xenobalanus globicipitis STEenstrup (dolphin barnacle) and Lepas pectinata LiNNÉ (goose barnacle). Internally, the sheath is approximately one-half the height of the compartment. Below the sheath the infolding of the wall is reflected by many strong inner ribs, one primary and 3-7 secondary. On each side of the large midrib bluntly ended, secondary and tertiary riblets from below the sheath extend downwards and sharply ended inside the bluntly ended outer ribs. Externally, each of the compartments is apparently solid and has a more or less distinct median sulcus. The sutural surface between the compartments is deep, either medium or narrow and transversely grooved (Figs. 10a-c).

The development of the opercular valves greatly varies irrespective of the 
growth of the outer wall (Figs. 10a, 11f). They are seated on the outer surface of the projecting opercular hood near the orificial edge; the scutum is moderately developed, oblong or spoon-shaped, while the tergum is less developed or rudimentary, elongate, both ends being truncate and bent inwards.

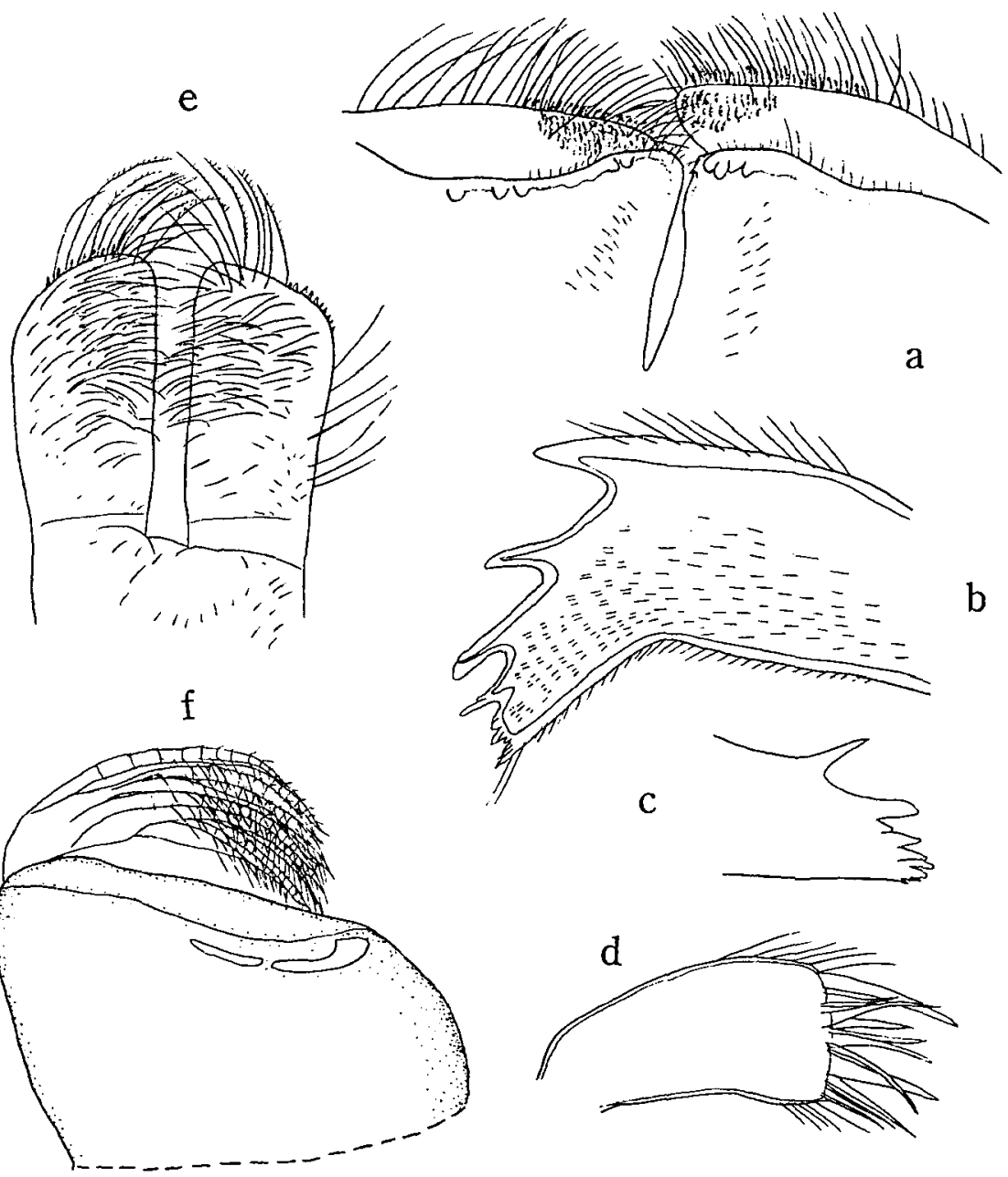

Fig. 11. Platylepas ophiophila LAnchester from Mano Bay, Sado Is. a, Labrum and palpi; $b, c$, mandible; $d$, maxilla I; $e$, maxilla II, paired; $f$, opercular hood with rudimentary opercular valves and cirri, side view. $(a, e \times 53 ; b . d \times 80 ; f \times 13)$

The mouth-parts (Fig. 1 la-e) almost conform to the characters of the related P. hexastylos (cf. Hiro, 1937, p. 472, fig. 43), but differ in details. The palp is small, elongated in parallel with the cutting edge of the labrum, and fringed with a number of incurved pectinate bristles and covered densely with long, simple bristles on the 
outer surface. The labrum is bullate and provided with 3 obtuse teeth on each side of a deep notch in the middle on the inner surface of the hairy outer rim. The mandible is narrow and has four strong teeth and a pectinated lower angle. The maxilla $I$ is narrower, with 10 spines along the straight frontal edge. The maxilla II is large, bilobed, and terminally armed with long, comb-like bristles and a series of spinules at the truncated distal end.

The cirri are much developed and laterally flattened and have 5 pairs of long, stout setae along the ventral edge of each segment. The numbers of segments in the cirri for a $7.5 \mathrm{~mm}$ long specimen are as follows:

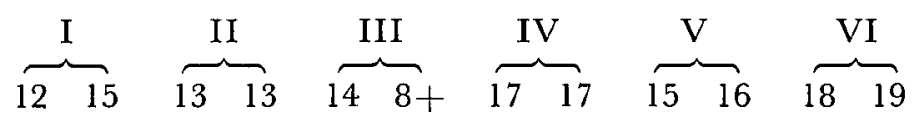

The penis is very long, finely annulated and scarcely hairy and gradually tapers to the truncated end, extending far beyond the end of the last cirri in the preserved state.

Remarks.-Presumably, this sea-snake harboring barnacle may be practically scarce as museum specimens in the world, so that it might have hitherto been variously named by previous authors (Platylepas ophiophilus LAnghester, P. krigeri Pilsbry, Platylepas decorata Nilsson-CANTEll and Cryptolepas ophiophilus KRÜGER). It seems likely that the apparent disagreement between the description and illustration of LANChester's original Platylepas opiophilus from Malay Peninsula and those of KRÜGER's Cryptolepas ophiophilus (=Platylepas kruigeri PILSBRY) from the Bay of Bengal may be due to their rough dissection and careless observations or drawings. All of the various names cited above are thus possibly synonymous, as I now concluded.

This conclusion is based partly on re-examination on materials on the skin of Enhydris (=Lapemis) hardwicki GrAy caught in South China Sea on June 19th, 1898 which might be the same source as Broch (1931) previously identified as Platylepas krugeri (?) and asked me by Dr. Torben WoLfF of the Zoological Museum of Copenhagen for identification, and examination on the materials_from an unknown sea-snake from Dhanushya Kodi, South India which was presented by Dr. A.B. WAGH of the Bombay Institute of Oceanographic Research for identification.

PILSBRy's Platylepas hexastylos var. ichthyophila from Lepisosteus caught in brackish water of Florida may be a valid species, closely resembling this $P$. ophiophila, rather than P. hexastylos. Another fossil (?) Platylepas wilsoni Ross (1963) recently discovered from Florida Pleistocene bed may also be a valid species, closely related to P. ophiophila.

47. Stomatolepas elegans (CosTA, 1838) サカヅキフジツボ (新称)

For synonymy and description see HiRo, 1936, p. 312, figs. 1-5.

Occurrence.-Tassya, Aikawa, Sado Is., on the carapace of Dermochelys coriacea, 
together with Platylepas hexastylos, leg. T. KiтAмI, 14/II '69.

Distribution.-Recorded only from Italy (Mediterranean), Florida and Nova Scotia (North Atlantic), Seto, Kii Pen. Japan (North Pacific) and New Zealand (South Pacific), imbedded in the skin of sea turtles (Caretta, Chelonia and Dermochelys).

\section{Regional Fauna and Collecting Data}

1. West coast of HOKKAIDO

Osyoro Bay (Collected by Dr. T. Uchida, VIII '34, Dr. S. Motoda, 29/X '43)Pollicipes mitella, Chthamalus challengeri, Balanus crenatus and B. cariosus

Iwanai and Esasi (Collected by Dr. S. MотоdA, 29/IX '43)-

Pollicipes mitella, Ch. challengeri, and B. cariosus

(2) Tugaru Strait

Hokodate, Hokkaido (Collected by Dr. M. Tokuda, 18/VII '32 and Weltner's record)-

Pollicipes mitella, Chthamalus challengeri, Ch. dalli and B. cariosus

Cape Tappi-saki (Collected by the late Dr. S. Hozawa, 22/VIII '29; Dr. N. ABE, $6 / \mathrm{V} \cdot 32)$ -

Tetraclita squamosa japonica, Balanus tintinnabulum rosa and $B$. trigonus

Off Siriya-zaki (Collected by the Sôyô-maru Benthic Survey 1926-1930)-

Octolasmis minuta nipponica, B. rostratus

(3) Mutu Bay (Collected by the late Dr. S. Hozawa, the late Dr. T. Tamura,

Dr. Hoshiai, Dr. Sh. Mawatari and myself).

Asamusi and Nohezi-

Pollicipes mitella, Lepas anatifera, Octolasmis neptuni, Ch. challengeri, Octomeris sulcata, T. sq. japonica, B. tin. rosa, B. trigonus, B. rostratus, B. hesperius

Ominato Port-

B. amphitrite and $B$. albicostatus

(4) Northwest coast of TOHOKU District

Hukaura, Tugaru Region (Collected by Mr. K. Konno, 29/IX '69)-

Pollicipes mitella, Lepas anatifera, L. anserifera, Ch. challengeri, Tet. sq. japonica, Tetraclitella darwini and $B$. tint. rosa

(5) Southwest coast of TOHOKU District

Kamo (Coll. by Mr. M. Inaba, X '64, Dr. S. Suzuki '58)-

$B$. eburneus and B. crenatus

Nezugaseki and Tobi-sima, Yamagata-ken (Collected by S. Suzuki and myself)Oxynaspis pacifica, L. anatifera, $L$. anserifera, Het. quadrata, Ch. challengeri, Octomeris sulcata, B. crenatus, B. trigonus, B. albicostatus, Tet. sq. japonica, Tetraclitella darwini

(6) HOKURIKU District

Awasima and Sado Islands (Collected by Dr. M. Tokuda, Mr. S. Sakai, Mr.

Y. Moriya and Mr. K. Kitami)-

Poll. mitella, L. anatifera, L. anserifera, L. pectinata, L. fascicularis, Octolasmis weberi, 
Par. minuta nipponica, Conch. virgatum, Conch. virgatum hunteri, Ch. challengeri, Oct. sulcata, T. sq. japonica, B. eburneus, B. venustus venustus, B. amphitrite, B. albicostatus, $B$. rostratus, $B$. socialis, Chel. testudinaria, Platylepas hexastylos, Pl. ophiophila, Stomatolepas elegans

Niigata Port (Collected by the late K. Ikeda and the late K. Hirasaka, Dr. Honma and Dr. Koseki)-

P. mitella, L. anatifera, L. anserifera, Ch. challengeri, B. tintin. rosa, B. eburneus, $B$. socialis

Toyama Bay (Collected by Mr. K. Kikuchi, '35 and Mr. K. Suzuki, '65-'69)P. mitella, Smilium scorpio, L. anatifera, Conchoderma virg. hunteri, Paralepas minuta nipponica, Tetraclitella darreini, B. tin. rosa, B. trigonus, B. rostratus, Acasta japonica, Chelonibia testudinaria

West coast of Noto Peninsula (Collected by myself '35 and Mr. K. Suzukr, '65'69)-

B. rostratus, B. granulatus, Platylepas hexastylos

(7) KINKI District

Wakasa Bay (Collected by Mr. M. Hiraguchi, Mr. Y. Yamamoto, H. Kitamura, late Dr. S. SAito, Mr. T. Yasuda, Dr. Sh. Fuse and myself)-

$P$. mitella, Smilium scorpio, Paralepas minuta nipponica, $C$. challengeri, $B$. improvisus, $B$. eburneus, $B$. venustus venustus, $B$. reticulatus (now perished), $B$. trigonus, $B$. amphitrite, Platylepas hexastylos, B. tin. rosa, B. tin. volcano, L. anatifera, Oct. angulata, Oct. neptuni, Tet. sq. japonica.

Tango-Tazima Region (Collected by Messrs. A. Hosomi, S. Nishimura and T. YAMAMOTO and WeLTNER's record)-

P. mitella, Smilium scorpio, Ch. challengeri, Oct. sulcata, Tlla. chinensis, Tlla. pilsbryi, Tet. sq. japonica, B. tin. rosa, B. trigonus

(8) SAN-IN District (Collected by Dr. T. Kamita, Mr. T. Iga and T. Yamamoto). Lakes Nakaumi and Zinzai-ko, Simane-ken-

B. tintin. rosa, B. tint. volcano, B. improvisus, B. uliginosus, B. albicostalus

Oki Islands-

Ch. challengeri, B. tin. rosa, Tet. sq. japonica

(9) Tusima Strait and Northern KYUSYU

Yosimi, Simonoseki (Collected by Mr. Y. MrYA, '69)-

Pollicipes mitella, Ibla cumingi, Ch. challengeri, T. sq. japonica, B. albicostatus, $B$. amphitrite, B. trigonus, $B$. variegatus cirratus

Tuyasaki, Hukuoka-ken (Collected by Dr. Y. Dotsu and Mr. H. Minei)$B$. tin. rosa, B. trigonus

Sigasima, mouth of Hakata Bay (Collected by Mr. K. Arakawa and Y. Mrya)Pollicipes mitella, Ch. challengeri, Ch. pilsbryi, B. amphitrite, B. tin. rosa, B. tin. volcano, B. albicostatus, B. eburneus

Hakata Bay and environs (Collected by Dr. S. Mryake, Mr. Y. MryA, Mr. S. Oyogi and Mr. T. ARITA)- 
Pollicipes mitella, Ibla cumingi, Telraclitella chinensis, B. eburneus, B. reticulatus, $B$. amphitrite, $B$. albicostatus, Chelonibia testudinaria

Iki Island (Collected by Dr. M. TokudA and Zool. Inst. of Tokyo Univ.) $T$. sq. japonica, B. tin. rosa, B. uliginosus, B. trigonus, B. variegatus cirratus

Nakanosima and Okinosima Islands, Tusima Strait (Collected by Dr. S. Mryake, '33, '58)-

Tusima Island (Collected by Zool. Inst. Tokyo Univ., Mr. H. MineI and Mr. Y. MrYA, VIII '69)-

Pollicipes mitella, B. trigonus, $B$. amphitrite

(10) SOUTH KOREA (Collected by the late Dr. S. Okuda, VII '36 and Mr. K. YaMAUChI, X '69 and BRoch's and Sôyô-maru Survey's records).

Southern insular Region-

Scalpellum koreanum, Octolasmis orthogonia, Oct. neptuni, Ch. challengeri, T. sq. japonica, Tetraclitella chinensis, B. amphitrite, B. uliginosus

Cheju-Dô (Querpart Is.) -

Pollicipes mitella, Ch. challengeri, T. sq. japonica, Tetraclitella chinensis, Tetraclitella darwini, Balanus albicostatus

\section{Discussion and Summary}

Analyzing the faunal composition of the coastal Cirripedia in the southeastern part of the Japan Sea, it is composed of the following elements:

(1) Boreal form

e.g. Chthamalus dalli, Balanus crenatus, B. cariosus, B. hesperius and B. rostratus

(2) Austral form

e.g. Pollicipes mitella, Ibla cumingi, Octomeris sulcata, Chthamalus challengeri, Ch. pilsbryi, Tetraclita squamosa, Tetraclitella spp., Balanus tintinnabulum, $B$. variegatus and $B$. socialis

(3) Widspread warm-water form (*Recent invaders of occidental origin) e.g. Balanus eburneus*, B. improvisus*, B. reticulatus, B. amphitrite, B. trigonus, B. venustus*

(4) Endemic warm-water form of oriental origin

e.g. Balanus albicostatus, $B$. uliginosus

Most of these littoral barnacles are common in Japanese coastal waters and locally abundant. Among them, the boreal cirriped fauna appears to be fairly well established around Hokkaido (HIro, 1935) and some of the boreal species penetrate southwards into middle Honsyu along the Pacific coast by means of the cold Oyasio Current (Hiro, 1939a; Utinomi, 1955).

On the other hand, the west coast of Japan is fairly washed by the warm Tusima Current, a branch northerly going from the west of Kyusyu through Tusima and Korea Straits, in contrast to the west coast of the Japan sea, namely the maritime region of Soviet Russia and North Korea under the influence of the cold Liman 
Gurrent. Therefore, the boreal forms are little found on the west coast of Japan, except the west coast of Hokkaido. In fact, only 2 species (Balanus crenatus and $B$. rostratus) were obtained in this survey, as occurring on benthic animals or things in the upper subtidal zone and not growing to such a large size as in those found on the Pacific coast of Tohoku District (northern Honsyu) and Hokkaido.

Most interesting is the fact that has been elucidated by this distributional survey carried out to witness the range extension of coastal barnacles in recent years in connection with the direction of currents and the change of hydrographical

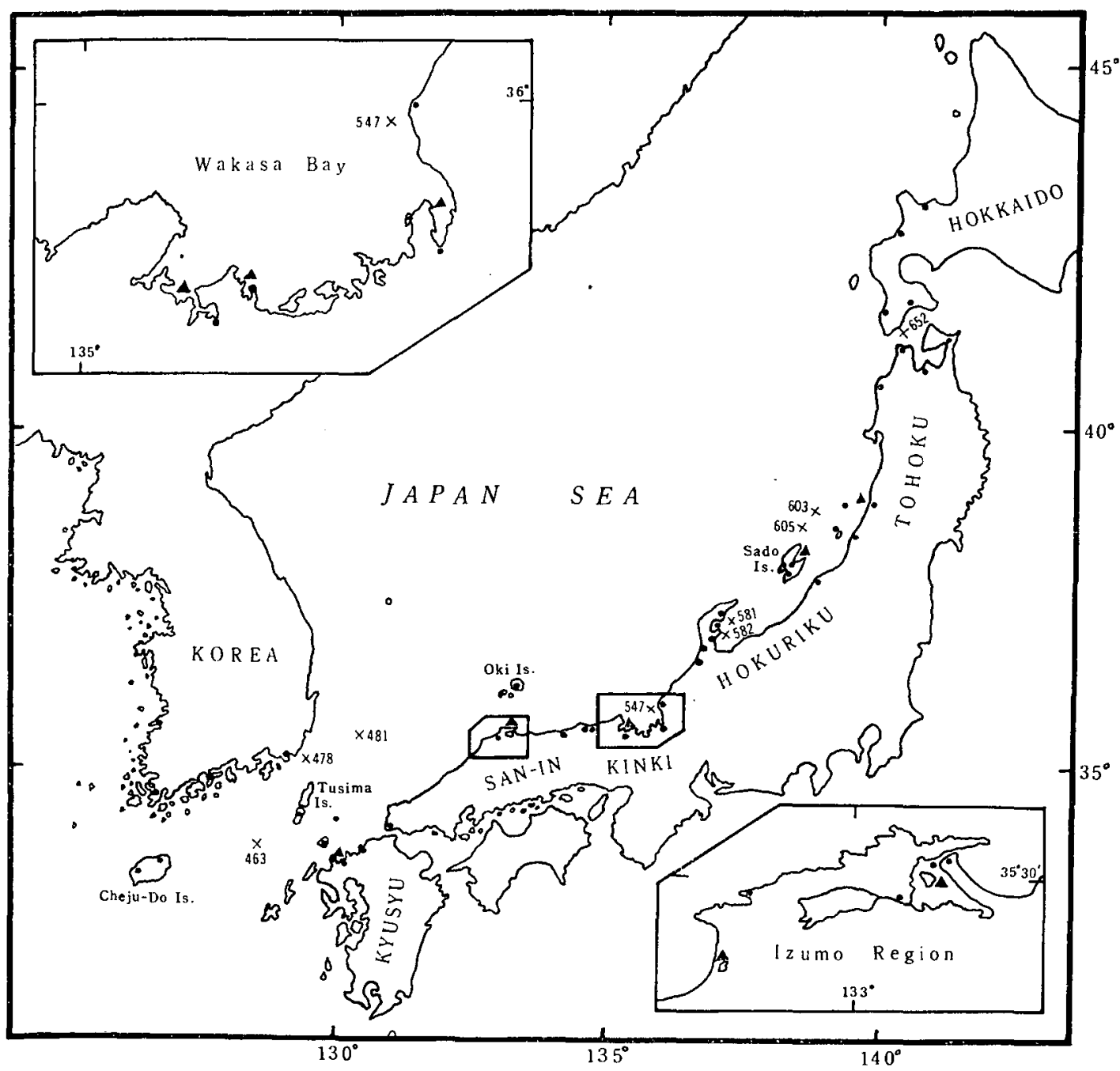

Fig. 12. Map of the Japan Sea surrounded by Japanese Main Islands and Korean Peninsula, showing the collecting sites (e) and the offshore stations of the Soyô-maru Benthic Survey 1926-30 ( $\times$ ) (those on the Pacific coast are omitted).

A Localities of recent invaders (B. eburneus or B. improvisus) 
circumstances occurred before and after the Second World War; namely I have confirmed the evidences of recent introduction of at least three occidental barnacles (B. eburneus, B. improvisus, and B. venustus) into the southeastern part of the Japan Sea (UTinomi, 1966). It seems likely that the invasion of these occidental fouling barnacles has been made by ships and further extension of their range in new regions may attribute to the dispersal of the nauplius larvae accomplished primarily by water currents. The pertinent water currents in the geographic range in the Japan Sea are the northerly-going warm Tusima Current and stable inshore current and eddy systems (cf. Matsur, Shane and Newmax, 1964; Mawatari, Kitamura and KaWASHMA, 1968). In the concerned area there are recognized 4 distributional patterns, namely Hakata Bay, Izumo Region, Wakasa Bay and Sado Region (Fig. 12).

It is probable that their recolonization in these new regions has become established successfully or has been proceeding presently after the Second World War. Before the War time, Maizuru Cove on the southern coast of Wakasa Bay, which was an important one of the old Japan's navy ports, had been dominated by $B$. reticulatus but now is replaced by other domestic barnacles such as $B$. tintinnabulum rosa, $B$. trigonus and new invaders such as $B$. amphitrite and $B$. eburneus and $B$. improvisus. During the present survey I have found $B$. reticulatus only in Hakata Bay, a southwesternmost port where the water may be more saline as in ports facing on the Pacific coast.

Indeed, the comparison between data for the fouling investigations in Japanese harbors made in the pre-war time (SAITo, 1929) and in the post-war time (MAWATARI, 1967) suggests that the stenohaline barnacle like $B$. reticulatus may have declined to survive in the Japan Sea and have successively been replaced by euryhaline widespread forms such as $B$. amphitrite, $B$. trigonus, B. eburneus and B. improvisus in recent years.

In the insular inshore regions of southern Korea and inland waters of Izumo Region of San-in District, on the other hand, many domestic inshore forms are still prevalent as in the pre-war time.

\section{REFERENCES}

Aurivillius, C.W. 1894. Studien über Cirripeden. Kongl. Svenska Vetenskapsakad. Handlingar, 26(7): 1-107, pls. 1-9.

Broch, Hj. 1927. Studies on Moroccan cirripeds (Atlantic coast). Bull. Soc. Sci. Nat. Maroc, 7(1-3): 11-38, pls. I-II.

- 1931. Papers from Dr. Th. Mortensen's Pacific Expedition 1914-16. LVI. Indomalayan Cirripedia. Vidensk. Meddr fra Dansk naturh. Foren, 91 : 1-142.

Darwin, C. 1851. A monograph on the Subclass Cirripedia. The Lepadidae. London. 1954. A monograph on the sub-class Cirripedia. The Balanidae, Verrucidae, etc. London.

Gruvel, A. 1905. Monographie des Cirrhipèdes ou Thecostracés. Paris. 472 pp.

Harding, J.P. 1962. Darwin's type specimens of varieties of Balanus amphitrite. Bull. Brit. Mus. (Nat. Hist.), Zool., 9(7): 273-296, pls. 1-10.

Henry, D.P. 1957. Some littoral barnacles from the Tuamotu, Marshall, and Caroline Islands. Proc. U.S. Nat. Mus., 107(3381): 25-37, pls. 1-3. 
Hrro, F. 1932a. On barnacles collected at Sado, Miyake and Etorofu Islands and Hokkaido. Zool. Mag., Tokyo, 44(530): 467-476. (In Japanese)

1932b. Report of the biological survey of Mutsu Bay. 25. Cirripedia. Sci. Rep. Tohoku Imp. Univ., 4th ser. Biol., 7(4): 545-552.

1933. Report on the Cirripedia collected by the surveying ships of the Imperial Fisheries Experimental Station on the continental shelf bordering Japan. Rẹc. Oceanogr. Wks. in Japan, 5(1) : 11-84, pls. I-III.

1935. The fauna of Akkeshi Bay. II. Cirripedia. J. Fac. Sci. Hokkaido Imp. Univ., Ser. VI, Zool., 4(4) : 213-229, pl. X.

1936. Occurrence of the cirriped Stomatolepas elegans on a loggerhead turtle found at Seto. Annot. Zool. Japon., 15 (3) : 312-320.

1937. Studies on the Cirripedian fauna of Japan. II. Cirripeds found in the vicinity of the Seto

Marine Biological Laboratory. Mem. Coll. Sci., Kyoto Imp. Univ., Series B, 12(3): 385-478.

1938. On the Japanese forms of Balanus amphitrite Darwin. Zool. Mag., Tokyo, 50(6) : 299-313. (In Japanese.)

1939a. Studies on the Cirripedian fauna of Japan. V. Cirripeds of the northern part of Honsyu. Sci. Rep. Tohoku Imp. Univ., 4th Ser. Biol., 14(2-3): 201-218.

- - 1939b. Ditto. IV. Cirripeds of Formosa (Taiwan), with some geographical and ecological remarks on the littoral forms. Mem. Coll. Sci., Kyoto Imp. Univ., Ser. B, 15(2) : 245-284.

Honma, Y. 1968. A preliminary list of some marine animals from the seashore of Niigata City, faced on the Japan Sea. Sci. Rep. Niigata Univ., Ser. D (Biol.), 5: 25-45.

HoshiaI, T. 1964. Synecological study on intertidal communities. IV. An ecological investigation on the zonation of Asamushi coastal area with special reference to the re-formation. Bull. mar. biol. Sta. Asamushi, Tohoku Univ., 12(2/3): 93-102.

Hosomi, A. 1966. On the change of the fauna in the interior of the Zyuzi Cave and Anmakuti Cave. Rep. Speol. Survey of undersea and shore caves on the coast of Hamasaka, pp. 23-28. Published by Hamasaka Town-office. (In Japanese.)

Ichikawa, S. and M. Yamada. 1957. Catalogue of marine invertebrates near the Osyoro Bay. 13 pp. (In Japanese.)

IwasıwA, H. 1962. Marine invertebrates of the Kanaizumi coast, Sado Is. Sado Hakubutukanpô, 9: 7-12, pl. 1. (In Japanese.)

- 1966. Littoral fauna of the Japan Sea, with special reference to seashore observations at Sado. Tôsyo-Kôkôtûsin, (49): 6-8. (In Japanese.)

Kitami, T. 1968. A list of the cirriped Crustacea collected from the coasts of Sado and Awashima Islands. Sado Hakubutukanpô, 17: 11-13; Niigata Seibutu Kenkyûsi, 4: 68-74, pls. 1-2. (In Japanese.)

Koseki, T. and Sh. Yamanouchi, 1962. Estimation of postmortem interval of a skull by examining barnacles (Balants socialis) attached to it. Nippon Hôigakkaisi, 16(5-6): 295-300. (In Japanese.)

Krüger, P. 1911. Beiträge zur Cirripedienfauna Ostasiens. Abhandl. math.-phys. Kl. Bayer. Akad. Wiss., II Suppl.-Bd. 6 Abh.: 1-72, pls. I-III.

1912. Ueber ostasiatische Rhizocephalen. Anhang: Ueber einige interessante Vertreter der Cirripedia Thoracica. Ibid., 8 Abh.: 1-16, pls. I-III.

Lanchester, W.F. 1902. On the Grustacea collected during the "Skeat Expedition" to the Malay Peninsula. Proc. zool. Soc. Lond., 1902, II : 363-381, pls. 34-35.

Luckens, P.A. 1968. The breeding and settlement of Chthamalus challengeri Hock at Asamushi during 1967. Bull. mar. biol. Sta. Asamushi, Tohoku Univ., 13(2): 75-82.

Matsur, T., Shane, G. and W. Newman. 1964. On Balanus eburneiss Gould (Cirripedia, Thoracica) in Hawaii. Crustaccana, 7(2): 141-145.

Mawatari, S. 1967. Biological studies on fouling in Japanese harbors. I. General concept of researches. Misc. Rep. Res. Inst. nat. Res., 69: 87-114, pls. I-X. (In Japanese.)

Mawatari, Sh., Kitamura, H. and Y. Kawashima. 1968. Propagation of invaded barnacles by ships. Proc. Jap. Soc. syst. Zool, 4: 24-30, pl. V. (In Japanese.) 
Newman, W.A. 1960. Five pedunculate cirripeds from the western Pacific, including two new forms. Crustaceana, 1(2): 100-116.

1961. On certain littoral species of Octolasmis (Cirripedia, Thoracica) symbiotic with decapod Crustacea from Australia, Hawaii, and Japan. Veliger, 4(2): 99-107.

1967. Shallow-water versus deep-sea Octolasmis (Cirripedia, Thoracica). Crustaceana, 12(1): 13-32.

Nilsson-Cantell, C.A. 1921. Cirripedien Studien zur Kenntniss der Biologie, Anatomie und Systematik dieser Gruppe. Zool. Bidrag fr. Uppsala, 7: 75-395, pls. 1-3.

1927. Some barnacles in the British Museum (Nat. Hist.). Proc. zool. Soc. Lond. 1927 (3): 743-790, pl. 1.

1932. Cirripedien aus Japan, gesammelt von Dr. Smith, Dr. Harberer und Dr. Hilgendorf in dem Berliner Museum aufbewart. Ark. Zool., 24A(4): 1-30, pl. I.

- 1934. Cirripedes from the Malay Archipelago in the Zoological Museum of Amsterdam. Zool. Meded., 17(1-2) : 31-63.

1938. Cirripedes from the Indian Ocean. Mem. Ind. Mus., 13(1): 1-81, pls. 1-3.

Pilsbry, H.A. 1916. The sessile barnacles (Cirripedia) contained in the collections of the U.S. National Museum; Including a monograph of the American species. U.S. Nat. Mus. Bull. 93 : 366 pp., 76 pls.

1928. Littoral barnacles of the Hawaiian Islands and Japan. Proc. Acad. nat. Sci. Philadelphia, 79: 305-317, pls. 24-26.

1953. Notes on Floridan barnacles (Cirripedia), Ibid., 105: 13-28, pls. 1-2.

Ross, A. 1963. A new Pleistocene Platylepas from Florida. Quart. J. Florida Acad. Sci., 26(2): 150158.

1968. Bredin-Archibold-Smithsonian Biological Survey of Dominica. 8. The intertidal Balanomorph Girripedia. Proc. U.S. Nat. Mus., 125 (3663) : 1-22.

Rossell, Neon C. 1967. The Philippine Cirripedian fauna: I. Some pedunculate cirripeds from Iloilo waters and adjacent seas. Natur. applied Sci. Bull., 20(4): 227-319.

Saito, T. 1929. Studies on antifouling paints. I. Biological studies on marine fouling organisms. Published by Construction Division, Maizuru Secondary Naval Station, Maizuru. 52 pp., 51 figs. (in 21 pls.) and 9 tables. (In Japanese.)

Stubbings, H.G. 1967. The cirriped fauna of tropical West Africa. Bull. Brit. Mus. (Nat. Hist.), Zool. 15(6): 229-319, pl. I.

Suzuki, Sh. 1963. Fauna of the coast and the adjacent sea of Shônai. Published by the author. Yamagata. 43 pp. (In Japanese.)

Tarasov, N.I. and G.B. Zevina. 1957. Cirripedia Thoracica in the seas of USSR. Fauna SSSR, 6(1): 1-267, pl. 1. (In Russian.)

Utinomi, H. 1949. Studies on the Cirripedian fauna of Japan. VI. Cirripeds from Kyusyu and Ryukyu Islands. Publ. Seto mar. biol, Lab., 1(2): 19-37.

- 1954. Invertebrate fauna of the intertidal zone of the Tokara Islands. IX. Cirripedia. Ibid., 4(1): 17-26.

1955. Studies on the Cirripedia of Japan. II. Geographical distribution. Bull. biogeogr. Soc. Japan, 16-19: 113-123. (In Japanese.)

1962. Studies on the Cirripedian fauna of Japan. VIII. Thoracic cirripeds from western Kyusyu. Publ. Seto mar. biol. Lab., 10(2): 211-239.

1966. Recent immigration of two foreign barnacles into Japanese waters. Proc. Jap. Soc. syst. Zool., 2: 36-39. (In Japanese.)

1967. Comments on some new and already known cirripeds with emended taxa, with special reference to the parietal structure. Publ. Seto mar. biol. Lab., 15(3): 199-237, pl. VI.

1968. A revision of the deep-sea barnacles Pachylasma and Hexelasma from Japan, with a proposal of new classification of the Chthamalidae (Cirripedia, Thoracica). Ibid., 16(1): 21-39.

Yamaguchi, E. and M. Yamada. 1955. Marine invertebrates of northern Japan. Published by Kyoiku Hyôronsya, Ltd. 87 pp. [Cirripedia: 120-122.] (In Japanese.) 
Yasuda, T. 1968. Studies on the fouling organisms in Nyuura Bay, Fukui. III. Observations on the ecology of a cirriped, Balanus amphitrite amphitrite Darwin. Jap. Jour. Ecol., 18(1): 27-32. (In Japanese.)

WELTNER, W. 1897. Verzeichnis der bisher beschriebenen recenten Cirripedienarten. Arch. f. Naturg., Jahrg. 63(1): 227-280.

1922. Cirripedia der deutschen Tiefsee-Expedition. Wiss. Ergebn. deut. Tiefsee-Exped., 23 (2) : $59-112$, pls. $2-4$.

Wu, Shi-Kuei. 1967. Two new records of Octolasmid cirripeds from Taiwan. Crustaceana, 12(3): 274-278.

Zevina, G.B. and N.I. Tarasov. 1963. On the Cirripedian fauna of the southeastern Asia. Pt. 1. Trudy Inst. Okeanol., 70: 76-100. (In Russian.)

Zullo, V.A. 1966. The cirriped Stomatolepas elegans (Costa) on leatherback turtles from Nova Scotian waters. Canadian Field-Naturalist, 80 (3) : 162-165.

- 1968. Tesseropora Pilsbry (Cirripedia, Thoracica) from the Pliocene of the Gulf of California. Crustaceana, 15(3): 272-274, pl. I. 


\section{EXPLANATION OF PLATE XVW}

Fig. 1. Lepas fasticularis Ellis et Solander from Aikawa, Sado Island.

Fig. 2. Conchoderma virgatum hunteri (Owen) from Aikawa, Sado Island.

Fig. 3. Octomeris sulcata Nilsson-Cantell from Hutagosima, Asamusi, top view. $\quad \times 1.3$

Fig. 4. The same, side view. $\times 1.3$

Fig. 5. Tetraclitella chinensis (Nilsson-Canteli) from Kitaebisu, Aikawa, Sado Island, Top view. $\quad \times 3$

Fig. 6. Balanus tintinnabulum volcano PILSBRy from Awasima, side view. $\times 1$

Fig. 7. Balanus tintinnabulum rosa PrLsBRy (white form) from Aikawa, top view. $\times 0.8$

Fig. 8. Balanus eburneus Gould, from Kamo-ko, Sado Is., bottom view (basis removed). $\quad \times 0.8$

Fig. 9. The same, side view. $\times 0.8$

Fig. 10. The same, top view. $\times 0.8$

Fig. 11. Balanus venustus venustus DARwin from Kitaebisu, Aikawa, Sado Is., top view. $\times 0.8$

Fig. 12. Platylepas ophiophila Lanchester from Mano Bay, Sado Is., top view. $\times 3$

Fig. 13. The same, bottom view (basal membrane retained). $\times 3$

Fig. 14. The same, top view (intact specimen covered wholly with the snake's skin).

Fig. 15. Part of trunk of a sea-snake, with some specimens of Platylepas ophiophila, captured in Mano Bay, Sado Is. $\quad \times 0.6$

Photo: Dr. T. HoshiaI $(3,4)$ and Mr. T. Kitami (others). 
Publ. Seto Mar. Biol. Lab., XVII (5), 1970.
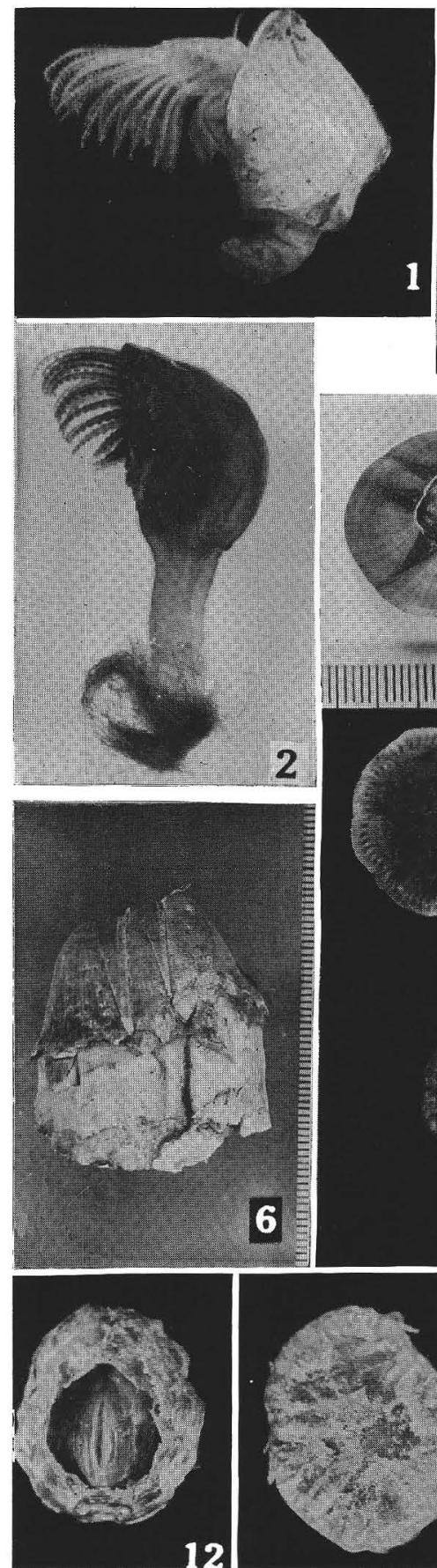

12
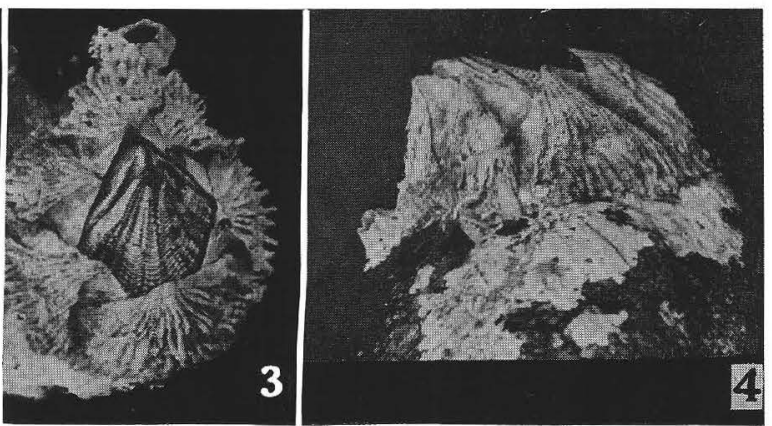

4
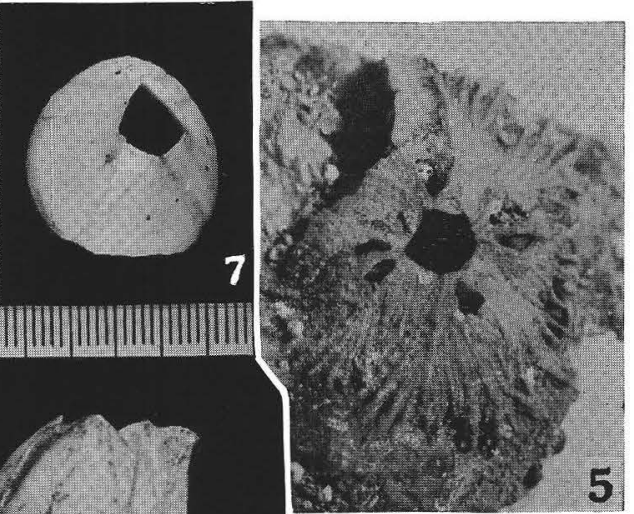

9

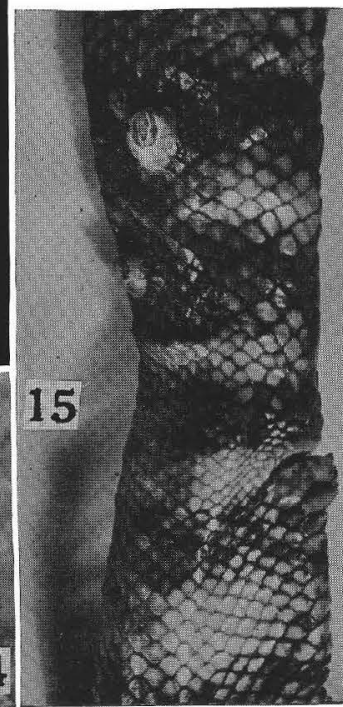

13

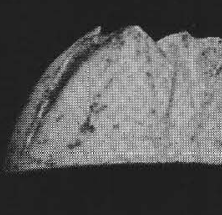

5

H. Utinom : Thoracic Cirripeds in the Japan Sea 